H. 422

RFP-2041

October 15,1973

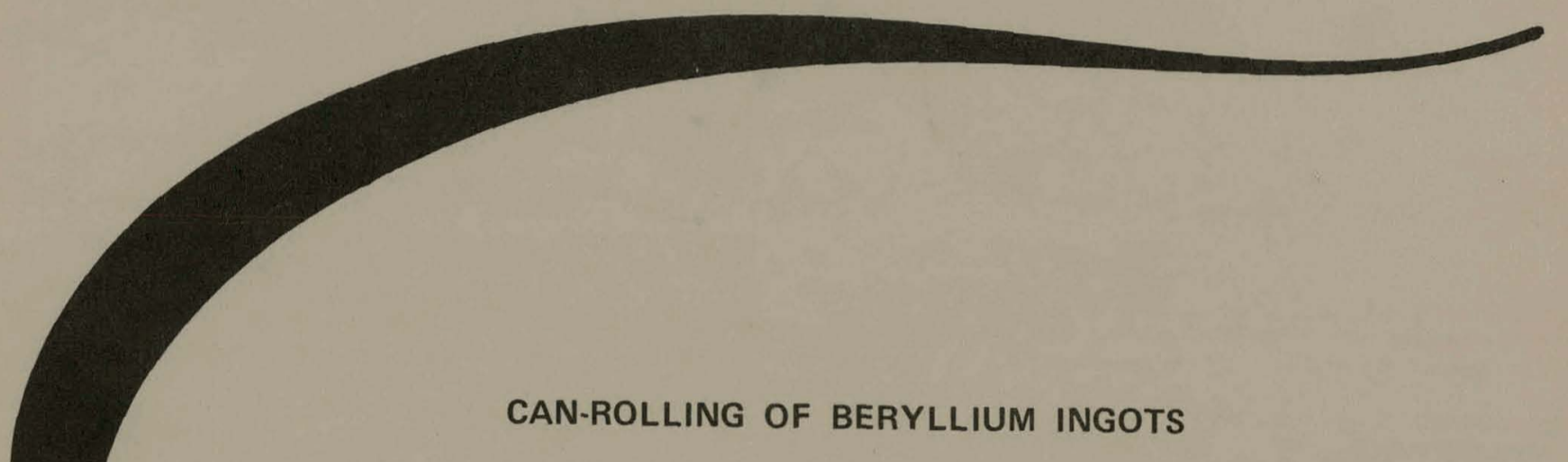

Dennis R. Floyd

William W. Leslie

Leon F. Dolechek

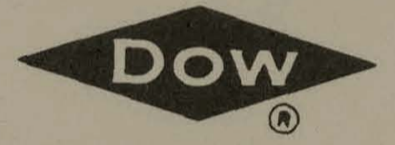

DOW CHEMICAL U.S.A. ROCKY FLATS DIVISION

P. O. BOX 888

GOLDEN, COLORADO 80401

U.S. ATOMIC ENERGY COMMISSION CONTRACT AT(29-1)-1106 


\section{DISCLAIMER}

This report was prepared as an account of work sponsored by an agency of the United States Government. Neither the United States Government nor any agency Thereof, nor any of their employees, makes any warranty, express or implied, or assumes any legal liability or responsibility for the accuracy, completeness, or usefulness of any information, apparatus, product, or process disclosed, or represents that its use would not infringe privately owned rights. Reference herein to any specific commercial product, process, or service by trade name, trademark, manufacturer, or otherwise does not necessarily constitute or imply its endorsement, recommendation, or favoring by the United States Government or any agency thereof. The views and opinions of authors expressed herein do not necessarily state or reflect those of the United States Government or any agency thereof. 


\section{DISCLAIMER}

Portions of this document may be illegible in electronic image products. Images are produced from the best available original document. 
This report was prepared as an account of work sponsored by the United States Government. Neither the United States nor the United States Atomic Energy Commission, nor any of their employees, nor any of their contractors, subcontractors, or their employees, makes any warranty, expressed or implied, or assumes any legal liability or responsibility for the accuracy, completeness or usefulness of any information, apparatus, product or process disclosed, or represents that its use would not infringe privately owned rights.

Printed in the United States of America

Available from the

National Technical Information Service

U. S. Department of Commerce

Springfield, Visginia 22.151

Price: Printed Copy $\$ 4.00$ Microfiche $\$ 0.95$ 
Printed

October 15, 1973
RFP-2041

UC-25 - MATERIALS

TID-4500-R60

\title{
CAN-ROLLING OF BERYLLIUM INGOTS
}

\author{
Dennis R. Floyd \\ William W. Leslie \\ Leon F. Dolechek
}

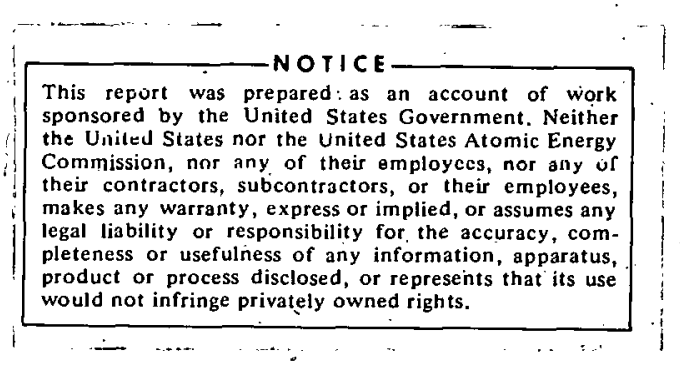

DOW CHEMICAL U.S.A. ROCKY FLATS DIVISION

P. O. BOX 888 GOLDEN, COLORADO 80401

Prepared under Contract AT(29-1)-1106 for the

Albuquerque Operations Office

U. S. Atomic Energy Commission 
RFP-2041

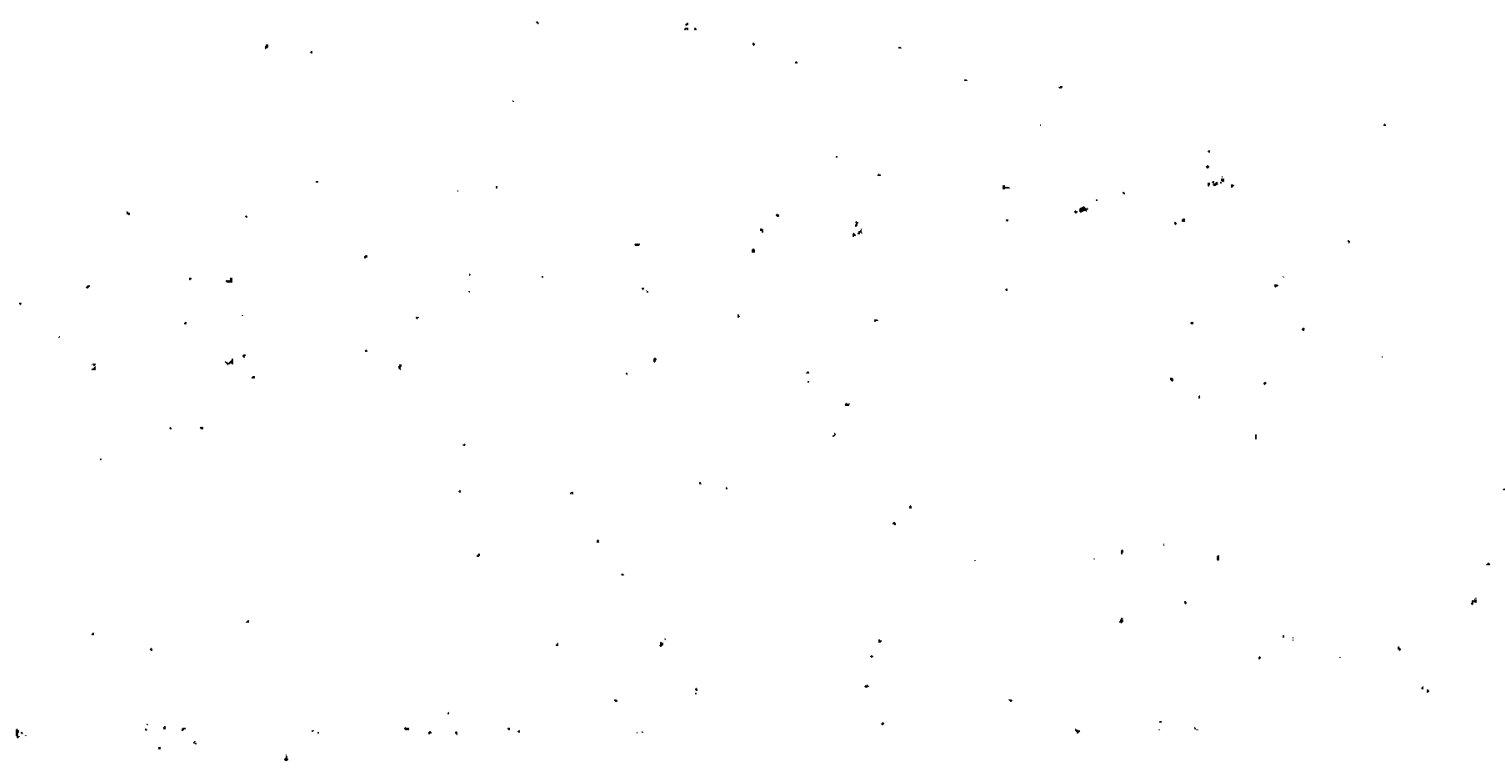




\section{CONTENTS}

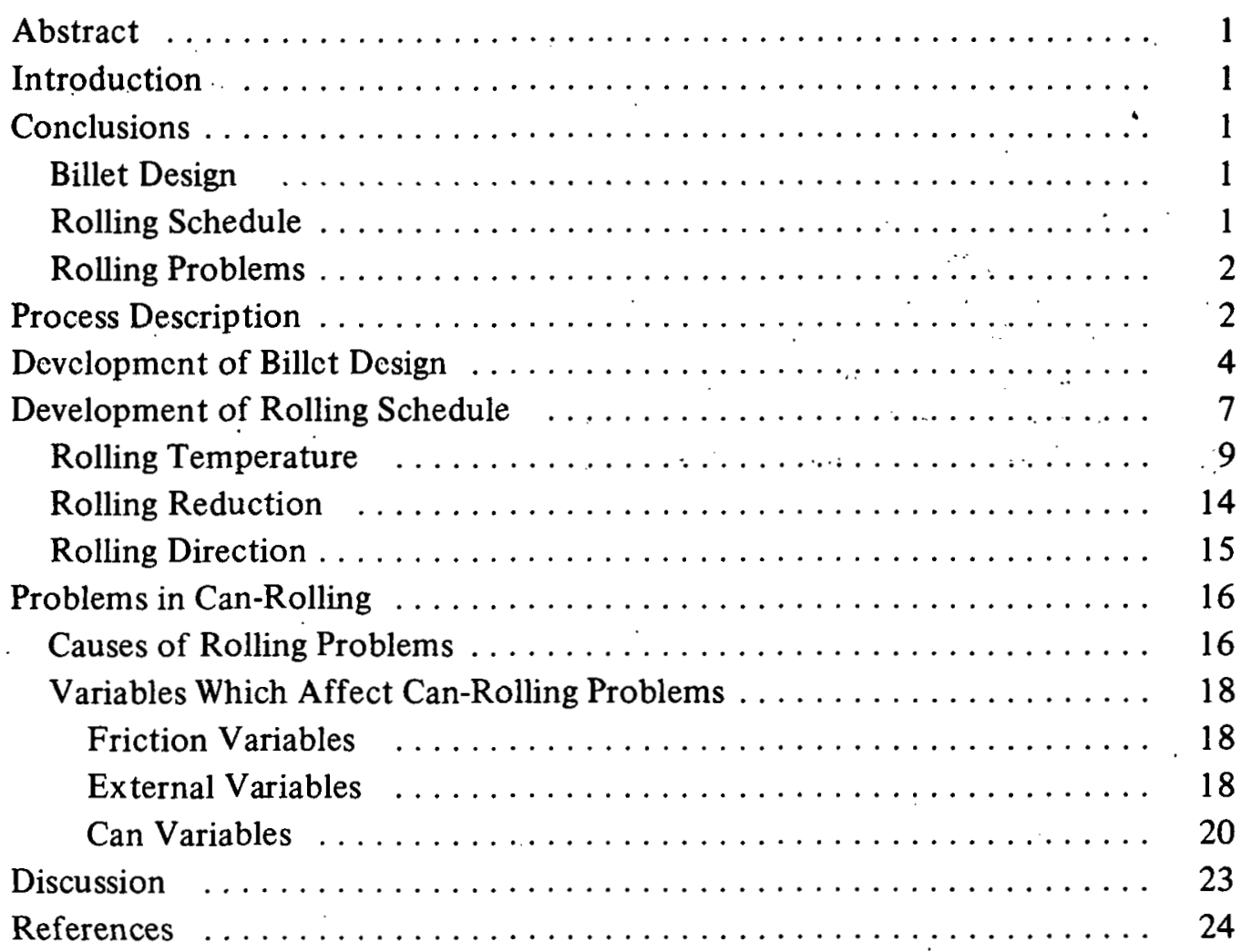




\section{ACKNOWLEDGEMENTS}

Since this report summarizes work done over a period of several years, many people have made significant contributions. Foremost among the early contributors was J. L. Frankeny who was in charge of the original development work and whose enthusiasm for developing a wrought fabrication process made the later work possible. K. E. Voiles did all the experimental casting work and made many of the rolling billets available. Rolling was done by Fabrication personnel supervised by J. J. Steger, J. D. Spruiell, and Q. J. Hammond. We are very grateful for the interest and many useful suggestions made by the rolling mill crews. They were indeed infected with the "R\&D spirit." Rolling mill operators were D. L. McHugh, V. J. Oster, C. V. Oswandel, and C. D. Pepper. The rest of the crew included, at various times: F. E. Adams, W. J. Dixon, N. Flick, L. P. Gehringer, A. Hoffmire, N. Jacobs, W. L. Jones, V. Kuretich, W. R. Mills, J. Saunders, E. J. Shantz, G. M. Snyder, and R. H. Thoren. Also, recent experimental work done by $C$. R. Heiple has been helpful in understanding the influence of several rolling variables. 


\title{
CAN-ROLLING OF BERYLLIUM INGOTS
}

\author{
Dennis R. Floyd, William W. Leslie, and Leon F. Dolechek
}

\begin{abstract}
This report deals with problems found in hot-rolling cast-beryllium billets canned in 304 stainless steel. Emphasis is placed on the development of the proper rolling schedule to completely convert the columnar cast structure to a uniform equiaxed one. Also emphasized are curling difficulties found in rolling this two-metal composite. The curling is found to depend chiefly on friction between the billet and work rolls. Lubrication and roll surface finish are found to be the key variables which in turn control friction. Curling is best prevented by having a higher friction coefficient on the bottom billet surface than on the top during rolling.
\end{abstract}

\section{INTRODUCTION}

Dow Rocky Flats has been engaged in the process of transforming beryllium castings into usable sheet since 1962. The process involves casting sound beryllium ingots as a material source for rolling billets. The billets are sheathed in $5 / 8$-in.thick 304 stainless steel and hot-rolled to a beryllium thickness of 0.2 inch. This operation is described in this report as can-rolling, and the product resulting from the operation is called canrolled sheet. The beryllium is removed from the stainless steel can by square shearing. The shear blade slices through both the stainless steel and the beryllium and, since there is no bonding of the steel to the beryllium, the materials are easily separated.

This report deals with the problems encountered in can-rolling beryllium. This operation is the most critical of the many operations in the total ingot-sheet-beryllium process. Material defects found in subsequent operations most of ten originale in can-rolling. Consequently, a sizable effort has been expended to understand and improve the can-rolling operation. The purpose of this report is to summarize the results of the effort.
The report is intended primarily for those who are concerned with rolling beryllium metal within a protective can, regardless of whether the metal is ingot-source or powder-source beryllium. Hopefully, the report will also be useful to anyone interested in rolling two dissimilar metals simultaneously, such as with rolling of composites.

\section{CONCLUSIONS}

\section{Billet Design}

- Both the round and the square billet cross sections have been used successfully, but the square is preferred because it provides better utilization of material.

- Electron-beam welding is preferred to manual electro arc welding because it is faster and more easily repairable. However, both methods are acceptable.

- Type 304 stainless steel is superior to mild steel as a canning material chiefly because of its strength at high temperature which helps produce a smooth surface and prevent large grains in the resulting beryllium sheet. A serious drawback of stainless steel is its tendency to cold work during the grain refinement stage of rolling.

\section{Rolling Schedule}

- There exists a critical range of rolling temperatures and reductions during the hot-breakdown stage of rolling. The range extends over the first $77 \%$ reduction in thickness during which the temperatures must be above $1800^{\circ} \mathrm{F}$ to avoid retained cast structure in finished sheet. A schedule balancing reductions per pass and reheat frequency during this range has been developed 
and proven in production. Even minor departures from this schedule often result in large grains in the microstructure.

- A few rolling passes of up to $30 \%$ rèduction in thickness per pass during the hot-breakdown and intermediate rolling stages are less effective in breaking up the cast structure than several passes of 10 to $15 \%$ reduction per pass.

- Heavy reductions of about $20 \%$ per pass are preferred to lighter reductions during the grain refinement stage because of fewer curling problems and avoidance of reheat times between passes.

- Cross-rolling is preferred to unidirectional rolling because more unitorm mechañical propertles and microstructures result. Equipment limitations require that the last four passes be done in one direction and this causes severe anisotropy in the plane of the sheet. Bare rolling an equivalent amount in the cross direction will return the in-plane properties to a good balance.

\section{Rolling Problems}

- The major source of can-rolling losses is curling in the thickness range 0.750 to 1.3 inches. The losses result from rupturing of the can and/or cracking of the beryllium within it.

- Roll friction is the key variable affecting curling. Roll surface-finish and lubrication practice are the two factors having the greatest affect on roll friction. Curling is best avoided by having a rough finish and no lubricant on the bottom roll while a smoother finish and very light lubricant is used on the top roll.

- Two types of can ruptures occur. In one type the crack runs through the cover plate and in the other type it runs through the side plate. The former is a ductile failure caused by excessive thinning of one cover relative to the other. It may result from uneven deformation of the side rail during hot-breakdown or from curling. The side-plate rupture is the result of a fatigue type extension of the crack that originates on the inside of each can when the side rail is crimped down during rolling. This crack is harmless in most cans because it remains in the plane of the sheet, but it may turn and exit to the surface if the leading edge is bent back-andforth during the grain refinement stage.

- Lack ur cumplete peinetration of the clectronbeam weld can promote curling and subsequent rupture through the cover plate, but ultrasonic inspection methods effectively screen-out such defects.

\section{PROCESS DESCRIPTION}

The objective of the current process at Rocky Flats is to pronuce ingnt-source bervllium sheet 0.100 -in. thick with chemical purity and mechanical properties shown in Tablcs 1 and 2, respectively. Included in each table are the mean values and standard deviations for the current process.

Table 1. A Comparison of the Maximum Allowable Impurity Content with the Mean Value for Each Impurity that Results from the Standard IngotSheet-Beryllium Process.

\begin{tabular}{|c|c|c|c|}
\hline Impurity* & $\begin{array}{c}\text { Maximum** } \\
\text { Allowable } \\
\text { (ppm) }\end{array}$ & $\begin{array}{l}\text { Process Mean } \\
\text { (ppm) }\end{array}$ & $\begin{array}{c}\text { Standard } \\
\text { Deviation } \\
\text { (ppm) }\end{array}$ \\
\hline $\mathrm{BeO}$ & 500 & 50 & 0 \\
\hline c & 1200 & 720 & 110 \\
\hline $\mathbf{N}$ & 600 & $<100$ & - \\
\hline$F_{0}$ & 2500 & 1450 & 50 \\
\hline $\mathrm{Al}$ & 1200 & 660 & 40 \\
\hline $\mathrm{Si}$ & 1200 & 520 & 70 \\
\hline Mg & 500 & $<10$ & - \\
\hline $\mathrm{Ni}$ & 500 & 210 & 50 \\
\hline $\mathbf{T i}$ & 500 & 250 & 50 \\
\hline $\mathrm{Cu}$ & suo & $<100$ & - \\
\hline $\mathrm{Cr}$ & 500 & $<200$ & - \\
\hline
\end{tabular}

*Any other single metallic impurity shall not exceed $200 \mathrm{ppm}$. The minimum iron content shall be 1.5 times the aluminum content. ** Per specification 8115000

Beryllium billets are prepared by casting available solid scrap into ingots, which are then sawed and machined to the desired dimensions. Castings are made in a 6 b-in. inside diamèter Stokes vacuuminduction furnace, using a bottom pouring technique. To control solidification, a copper chill block is placed under the mold and cooling water is continuously circulated through it to promotc 
Table 2. Comparison of the Mechanical Strength Requirements of the Specification with Mean Values Obtained in 0.100-in. thick Sheet by Using the Standard Ingot-Sheet-Beryllium Process.

\begin{tabular}{|c|c|c|c|}
\hline & $\begin{array}{l}\text { Minimum } \\
\text { Required }\end{array}$ & $\begin{array}{c}\text { Process } \\
\text { Mean }\end{array}$ & $\begin{array}{l}\text { Standard } \\
\text { Deviation }\end{array}$ \\
\hline \multicolumn{4}{|l|}{ Longitudinal } \\
\hline Ultimate (psi) & $40,000^{*}$ & 49,700 & 500 \\
\hline $0.2 \%$ yield (psi) & 22,000 & 26,100 & 500 \\
\hline Filongation (\%) & 3.0 & 6.2 & 0.2 \\
\hline \multicolumn{4}{|l|}{ Transverse } \\
\hline Ultimate (psi) & $38,000^{*}$ & 43,700 & 700 \\
\hline $0.2 \%$ yield (psi) & 22,000 & 26,000 & 600 \\
\hline Elongation (\%) & 3.0 & 4.9 & 0.2 \\
\hline
\end{tabular}

*The average ultimate tensile strengths in the longitudinal and transverse directions shall be equal within 10,000 psi.

directional solidification. Molds, crucibles, and stopper rods are made of graphite which is coated with $\mathrm{BeO}-\mathrm{BeSO}_{4}$ to prevent a reaction with the molten metal. Control of chemistry is obtained using a double-melting technique in which feed ingots are made from scrap of unknown chemistry and remelted into production ingots after the feed material has been chemically analyzed. More details of this process can be found in Reference 1 .

Ingots are produced in two sizes, 9 in. by 9 in. by $20 \mathrm{in}$. and $4 \mathrm{in}$. by $9 \mathrm{in}$. by $12 \mathrm{inch}$. Two 4 -in. thick billets are sawed from the bottom of the 20 -in. ingots. Each billet is radiographed to determine the presence of cracks and segregation. Acceptable billets are then machined to $8.500 \mathrm{in}$. by $8.500 \mathrm{in}$. by $3.500 \mathrm{in}$. with machining tolerances of \pm 0.030 in. in the 8.500-in. dimension, and 0.015 in. in the 3.500-in. dimension. All edges of each billet are chamfered to prevent beryllium from contaminating the electron beam weld. The machined billets are cleaned with Bon-Ami ${ }^{\circledR}$ and water and vacuum baked to remove volatile material. Billets are subjected to an ultrasonic vapor degreasing operation to remove any remaining machining oil prior to being coated. A slurry of alumina, sodium silicate, and water is applied to the six faces of each billet to help prevent bonding between the beryllium and the stainless steel jacket during rolling.
The billets are then jacketed (canned) in 304 stainless steel in preparation for rolling. The welding process consists of making a square frame by tack-welding four equal pieces of stainless steel plate. To avoid fit-up problems in electron beam welding, the pieces are first machined to tolerances of $9.155 \pm 0.010$-in. by $3.530 \pm 0.005$-in. by 0.605 \pm 0.020 -inch. Next, a stainless steel plate 9.780 \pm 0.010 -in. square by $0.605 \pm 0.020$-in. thick is tack welded to the frame to form the bottom of the "can." A billet of beryllium is inserted into the can and a cover plate is clamped on top of the can and tack welded. With the completion of this operation the can is ready for electron beam welding.

A Sciaky (Sciaky Bros., Chicago, Illinois) electron beam welder is used to weld all twelve joints in the stainless steel can. Welding parameters are checked periodically to ensure that the welder is operating properly and that adequate penetration is being obtained. The electron-beam welding operation is done under vacuum $\left(10^{-6}\right.$ torr $)$ and therefore a vacuum environment exists within the can after welding. This is desirable because it helps to prevent excessive oxidation of the beryllium at the high temperatures used during rolling. The chamfered edges on the billets prevent beryllium from being drawn up into the weld when the electron-beam spikes clear through the stainless can. When the electron beam is turned off at the end of each pass, a shrinkage cavity normally appears on the surface of the can. This cavity is heliarc welded shut, leaving a small void under the surface which is later detected during ultrasonic inspection. This void is not believed to significantly affect the rolling characteristics of the can. A cut-away view of a typical can-rolling billet is shown in Figurc 1.

Each weld on a can is then ultrasonically inspected to determine weld soundness. Cause of rejection has been determined experimentally. Any weld having less than $80 \%$ penetration or an area of porosity greater than $50 \%$ of the wall thickness (with the exception of the heliarc closure areas described above) causes the can to be rejected. Such cans are rewelded in the electron beam welder and inspected again. Should a weld be found unacceptable a second time, the beryllium billet is removed by milling the can. A new can is then used to sheath the billet. 


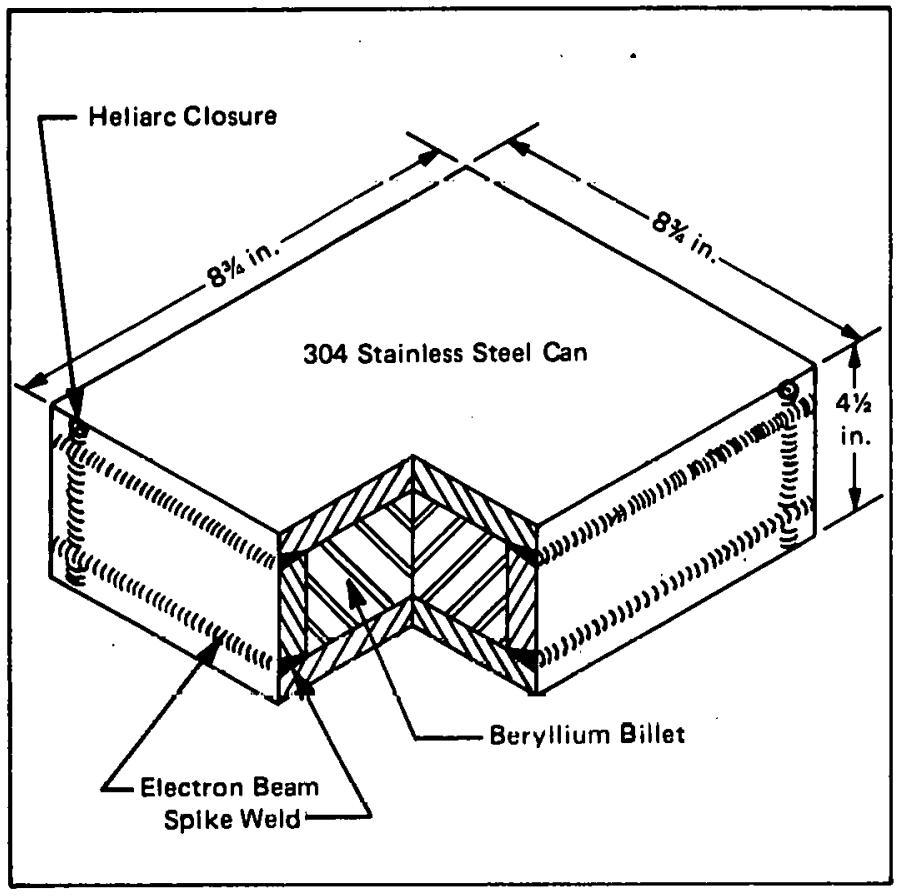

Figure 1. Cut-Away of a Typical Beryllium Rolling Billet.

Cans with acceptable welds are then rolled using the rolling schedule in Table 3 . The rolling is done on a 42-in. wide, 4-high Loewy mill with .12-in. diameter driven work-rolls, and backup rolls $42 \mathrm{in}$. in diameter. The maximum opening of the mill is 4.450 inches. The mill, shown in Figure 2, is rated at 5-million pounds of separating force and is powered by a 500-horsepower motor-generator set capable of reversing the roll direction and attaining full speed in 3 seconds.

\section{DEVELOPMENT OF BILLET DESIGN}

The rolling of sheathed (canned), vacuum-cast, beryllium billets was initiated at Dow Rocky Flats in 1962. From the program inception to the present time, the billet and can design has undergone major changes necessitated by the need of improving the quality and quantity of the finished product.

The original billet (6-in. dia. by 2 -in. thick) contained 56-cubic inches of beryllium and yielded a usable sheet approximately $14 \mathrm{in}$. in diameter at 0.250 -in. thickness. The volume of usable sheet
Table 3. Stendard Schedule Used to Can-Roll Ingot-Source Beryllium at Dow, Rocky Flats Division.

\begin{tabular}{|c|c|c|c|c|c|c|}
\hline \multirow[b]{2}{*}{$\begin{array}{c}\text { Rolling } \\
\text { Stage }\end{array}$} & \multicolumn{2}{|c|}{$\begin{array}{c}\text { Preheat } \\
\text { Conditions }\end{array}$} & \multirow[b]{2}{*}{$\begin{array}{l}\text { Pass } \\
\text { No. }\end{array}$} & \multirow[b]{2}{*}{$\begin{array}{l}\text { Gape } \\
\text { (in.) }\end{array}$} & \multicolumn{2}{|c|}{$\begin{array}{r}\text { Reduction In } \\
\text { Thickness (\%) }\end{array}$} \\
\hline & $\begin{array}{c}\text { Temp. } \\
\left({ }^{\circ} \mathrm{F}\right)\end{array}$ & $\begin{array}{r}- \text { Time } \\
\text { (min.) }\end{array}$ & & & $\begin{array}{l}\text { Per } \\
\text { Pass }\end{array}$ & Cumulative \\
\hline \multirow[t]{4}{*}{$\begin{array}{c}\text { Hot- } \\
\text { Breakdown } \\
\text { Stage } \\
\end{array}$} & 1900 & -600 & $\begin{array}{l}1 \\
2 \\
3 \\
4\end{array}$ & $\begin{array}{l}4.450 \\
4.150 \\
3.850 \\
3.550\end{array}$ & $\begin{array}{l}6.3 \\
6.7 \\
7.2 \\
7.8\end{array}$ & $\begin{array}{r}6.3 \\
12.6 \\
18.9 \\
25.3\end{array}$ \\
\hline & 1800 & -60 & $\begin{array}{l}5 \\
6 \\
7 \\
8\end{array}$ & $\begin{array}{l}3.250 \\
2.950 \\
2.650 \\
2.350\end{array}$ & $\begin{array}{r}8.5 \\
9.2 \\
10.2 \\
11.3\end{array}$ & $\begin{array}{l}31.6 \\
37.9 \\
44.2 \\
50.5\end{array}$ \\
\hline & 1800 & -45 & $\begin{array}{r}9 \\
10 \\
11\end{array}$ & $\begin{array}{l}2.050 \\
1.800 \\
1.550\end{array}$ & $\begin{array}{l}12.8 \\
12.2 \\
13.9\end{array}$ & $\begin{array}{l}56.8 \\
62.1 \\
67.4\end{array}$ \\
\hline & 1800 & -45 & $\begin{array}{l}12 \\
13\end{array}$ & $\begin{array}{l}1.300 \\
1.100\end{array}$ & $\begin{array}{l}16.1 \\
15.4\end{array}$ & $\begin{array}{l}72.6 \\
76.8\end{array}$ \\
\hline \multirow[t]{3}{*}{$\begin{array}{c}\text { Intermediate } \\
\text { Stage }\end{array}$} & 1600 & -50 & $\begin{array}{l}14 \\
15\end{array}$ & $\begin{array}{l}0.900 \\
0.750\end{array}$ & $\begin{array}{l}18.2 \\
16.7\end{array}$ & $\begin{array}{l}81.1 \\
84.2\end{array}$ \\
\hline & 1500 & -70 & 16 & 0.650 & 13.3 & 86.3 \\
\hline & 1500 & $-\quad 40$ & 17 & 0.550 & 15.4 & 88.4 \\
\hline \multirow{4}{*}{$\begin{array}{l}\text { Grain- } \\
\text { Refinement } \\
\text { Stage }\end{array}$} & 1400 & 35 & 18 & 0.440 & 20.0 & 90.7 \\
\hline & 1400 & -40 & 19 & 0.360 & 20.5 & 92.4 \\
\hline & 1400 & -40 & 20 & 0.280 & 22.2 & 94.1 \\
\hline & 1400 & -40 & 21 & 0.240 & 14.3 & 94.9 \\
\hline
\end{tabular}

was 38-cubic inches. This represents a yield of sound sheet of $68 \%$ of the input cast metal. The present rectangular billet design ( $8.5 \mathrm{in}$. by $8.5 \mathrm{in}$. by $3.5 \mathrm{in}$.) contains 253 -cubic inches and yields a usable sheet of $40 \mathrm{in}$. by $25 \mathrm{in}$. by $0.200 \mathrm{inch}$. The volume of usable sheet is 200 -cubic inches, which is a $79 \%$ yield. Therefore, better material utilization is realized from square, rather than from round billet designs.

Our first beryllium billets, 6 -in. dia. by 2 -in. thick, were machined from 7 -in. dia. by 10 -in. long vacuum cast ingots and canned as shown in Figure 3, No. 1. The rolling of this canned billet, with a $3 \%$ reduction and increasing to a $25 \%$ reduction on the final pass, was accomplished in thirteen passes through the rolling mill. The billet was initially heated to $1800^{\circ} \mathrm{F}$ and then was reheated 4 times during the rolling schedule; the last reheat temperature being $1500^{\circ} \mathrm{F}$. Beryllium sheet resulting from this 


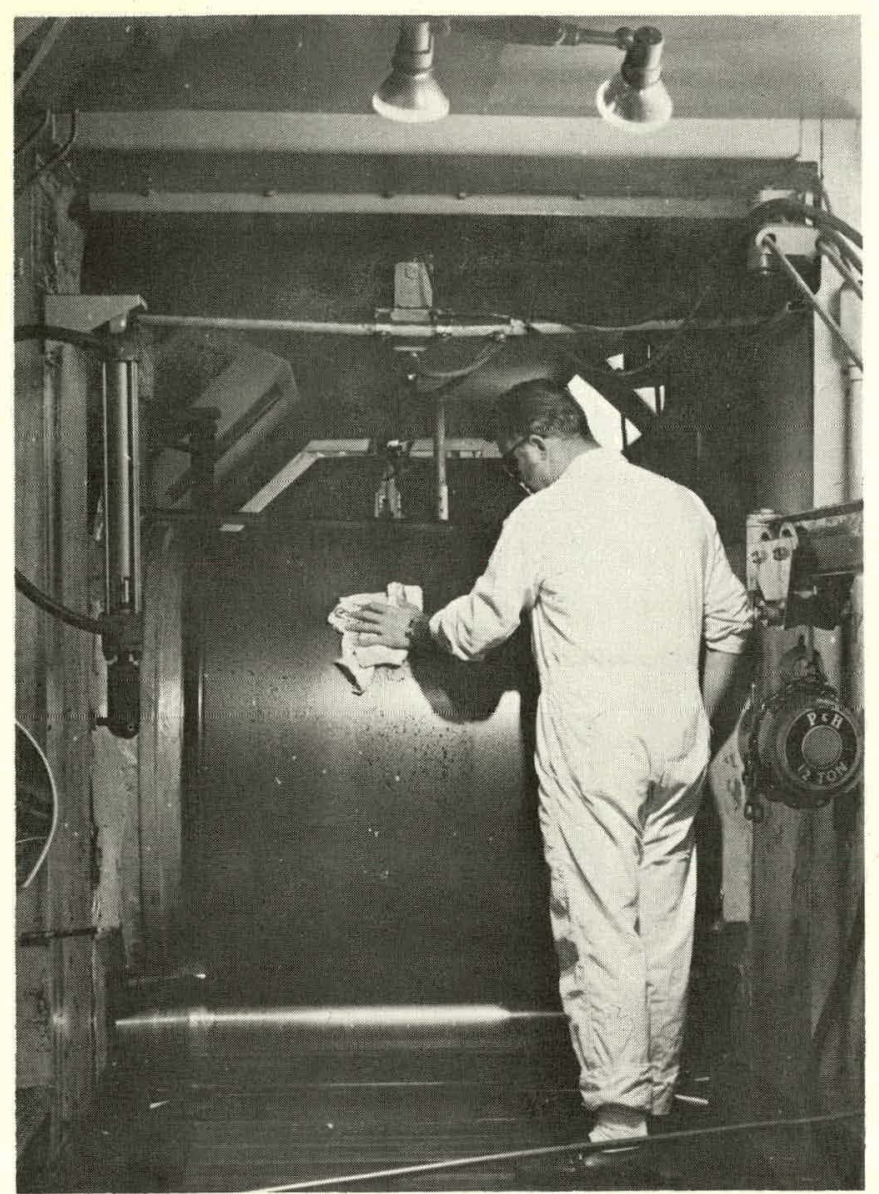

16869-2

Figure 2. Photograph Showing the Upper 42-in. Backup Roll and the 12-in. Work Roll of the Loewy Rolling Mill.

method of canning and rolling had a poor surface finish and thickness variations that made it unacceptable for forming.

To improve the surface finish and thickness uniformity, $5 / 8$-in. thick 304 stainless steel was tricd as a canning material. The beryllium billet size was increased to 6 -in. dia. by 3 -in. thick with the source of the rolling billets remaining the same (7-in. dia. by 10 -in. casting). The addition of a $1 / 8$-in. o.d. 304 stainless steel vent tube allowed the beryllium to be sealed under vacuum after assembly as shown in No. 2, Figure 3. Placing the beryllium under vacuum was intended to reduce the high temperature oxide buildup during rolling, and to keep the billet from outgassing to the point of pressurizing the can during rolling. The canned billet was rolled and reheated under conditions similar to those used for the low carbon steel can. The resulting sheet showed a definite improvement in thickness uniformity and surface finish and was a formable grade of ingot-sheet beryllium. Approximately 100 canned-beryllium billets of this design were processed. Data acquired from processing the 100 billets established the procedures for casting, canning, rolling, and forming, and definitely established the feasibility of the process.

The next major step was to improve the yield from each canned billet. This was done by developing a procedure for casting 11 -in. by 11 -in. by 15 -in. ingots. Three 10.5 -in. by 10.5 -in. by 3.5 -in. rolling billets were obtained from each casting and were canned as shown in No. 3, Figure 3. Again, $5 / 8$-in.-thick 304 stainless steel was used. A vent hole was included in this design to let the beryllium outgas during the initial heatup. The vent hole was sealed immediately prior to rolling by welding with $308-\mathrm{L}$ stainless steel rod. This can design and billet geometry was used only a limited time because of handling problems (the rolling billet weighed approximately 100 pounds and was manually handled at $1900^{\circ} \mathrm{F}$ ). However, it was used long enough to develop the rolling and reheat schedules.

The billet size was scaled down to the present 8.5-in. by 8.5 -in. by 3.5 -in. dimensions and canned in $5 / 8$ in.-thick 304 stainless steel. The can and billet design and welding method were the same as shown in No. 2, Figure 3. The weight was reduced to 74 pounds. This still caused a handling problem at $1900^{\circ} \mathrm{F}$, but it was tolerable. The yield was not appreciably affected by the decrease in the beryllium volume. This billet and can design went into production with approximately 500 units being rolled.

Eventually the manual stick-welding process, which took 6 hours per can, was replaced by an electron beam welding process which required only 1 hour per can.

The present billet, the can design, and the assembly are shown in No. 4, Figure 3. The details of this method are given in the Process Description section of this report. There have been approximately 1000 canned billets of this design processed. 

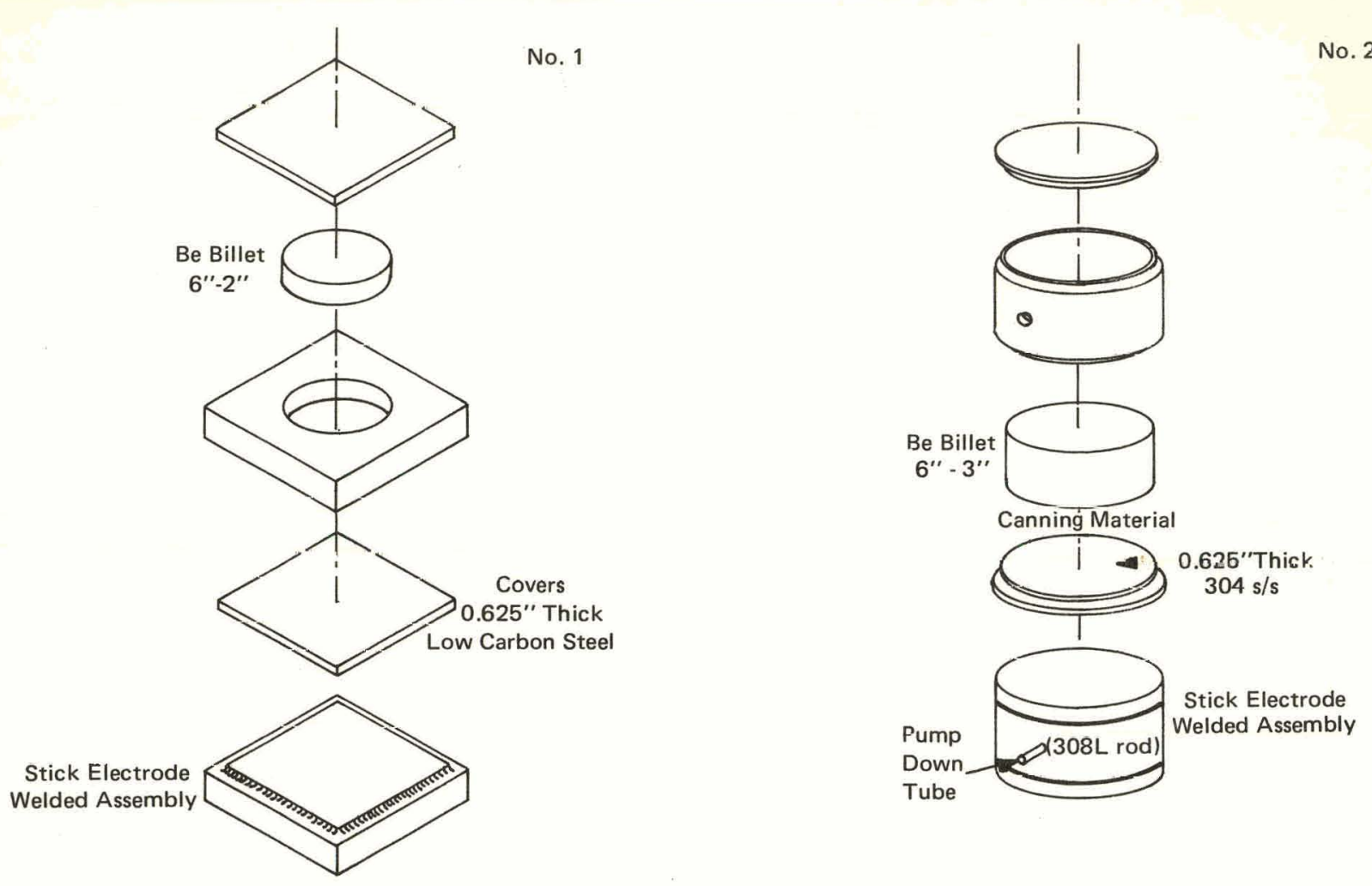

No. 2
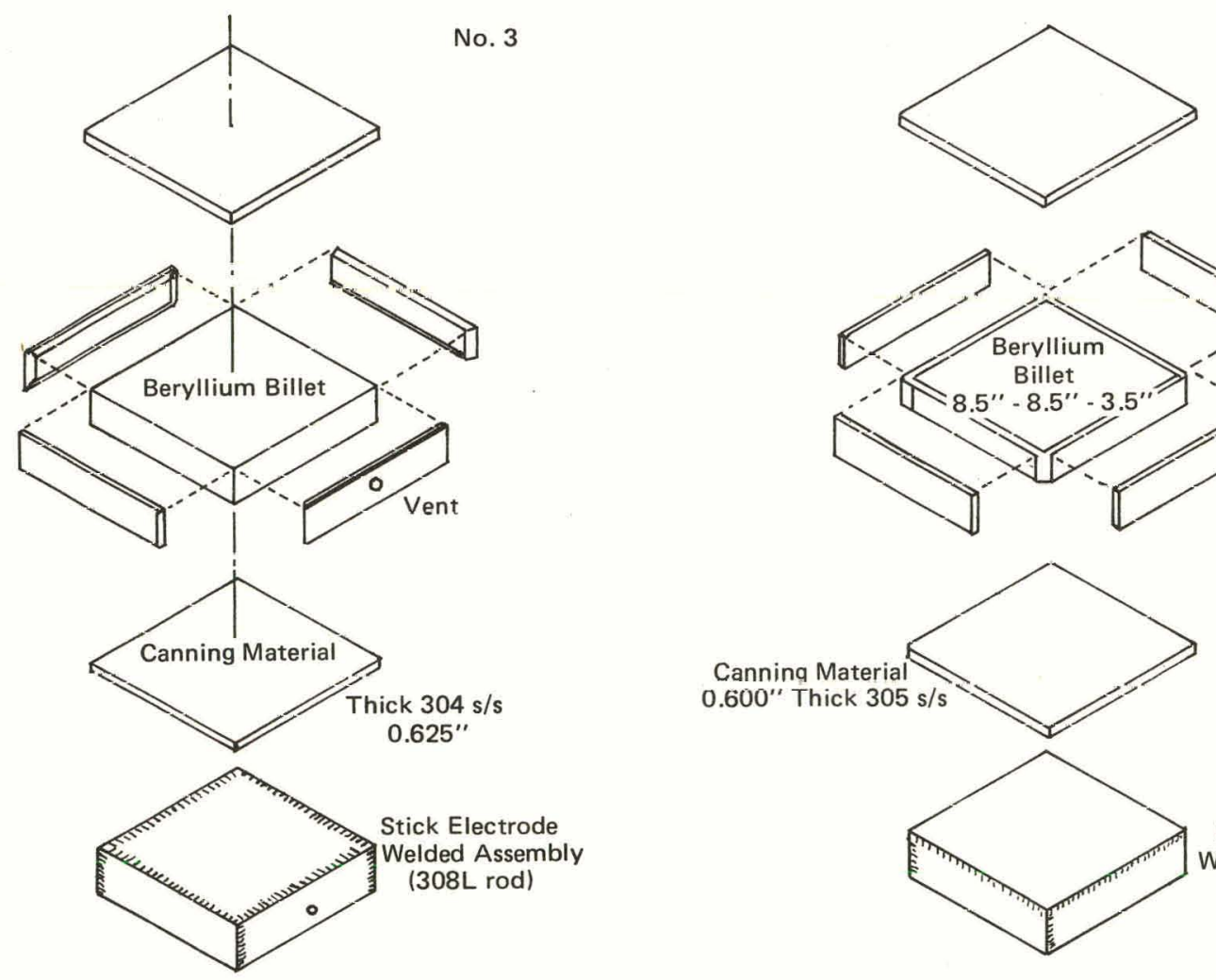

No. 4
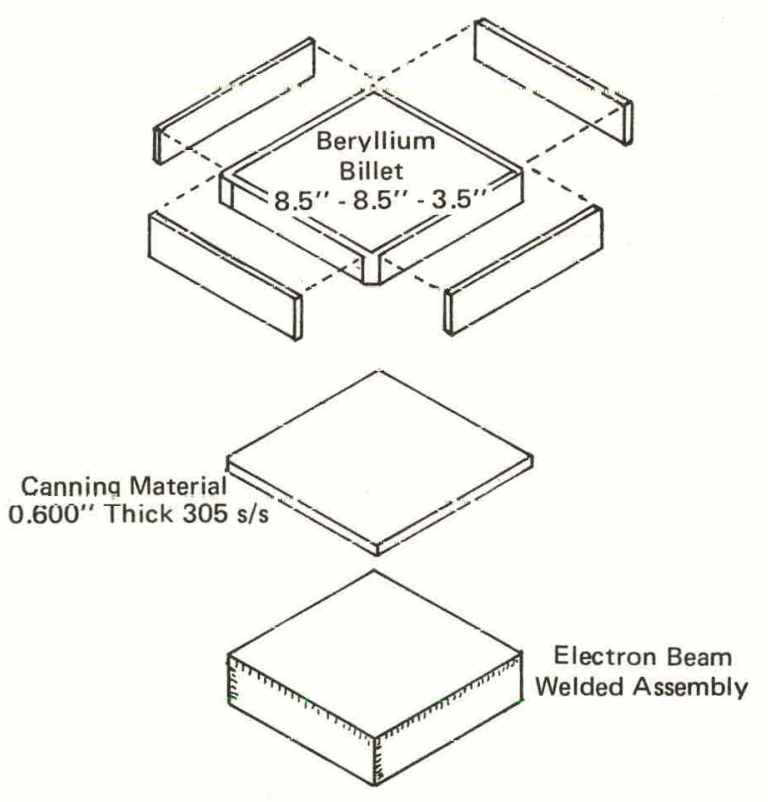

Figure 3. Four Different Methods that have been used to Clad Beryllium Billets for Rolling. 


\section{DEVELOPMENT OF ROLLING SCHEDULE}

The rolling schedule listed in Table 3 is the result of several years of production experience and development effort aimed at achieving high quality beryllium sheet at 0.100 -in. thickness. Measures of quality include grain size, mechanical properties, and uniformity. The sheet resulting from this schedule meets quality standards successfully. This is not to say that we consider the rolling schedule as optimum, because such things as the time required for processing, the number and size of billets rolled in a batch, the grain size at a given thickness, and the mechanical properties can still be improved. Rather, we consider the listed rolling schedule as adequate for our current needs.

During development of this schedule, many different rolling schedules were tried. This section of the report describes some of the more significant results of these trials. Basically what we are trying to do in rolling ingot beryllium is to convert the columnar cast structure to an equiaxed wrought structure with a minimum total reduction in thickness. In other words, we want to maximize the thickness at which the sheet is sound so that it can be used directly at that thickness, or it can be rolled further to achieve grain refinement. The reader should be aware of the following three things to put himself in proper perspective to understand this section: (a) the restrictions imposed on use by our equipment, (b) the variables that we can control to alter the rolling schedule, and (c) the measures we use to analyze our results.

\section{a. Restrictions}

1. Initial Billet Size - Because the gape of the mill is limited, we cannot exceed 5 in. total billet thickness, even though starting at a greater thickness would probably result in a proportionately greater thickness at which sound sheet could be achieved. Also, since the billets are maneuvered manually, the initial size cannol exceed 10 in. by 10 in. by $5 \mathrm{in}$. or the weight becomes excessive.

2. Mill Width - The maximum width of sheet that can be easily rolled on our 42-in. mill is
36 inches. This presents a serious limitation in planning a rolling schedule to achieve cross-rolling.

3. Furnace Size - The furnace available during most of the period when the rolling schedule was being developed was 32 -in. wide by 54 -in. deep. This restricts the number of billets that can be processed at a given time and the dimensions to which these billets can be rolled.

4. Sheathing Material - Generally 304 stainless steel is used. It is susceptible to severe work hardening, and hence embrittlement at temperatures below $1500^{\circ} \mathrm{F}$. Therefore we are restricted in the amount of reduction we can get in the grain refinement part of the schedule $\left(1400^{\circ} \mathrm{F}\right)$ without cracking the can.

\section{b. Major Variables}

1. Rolling Temperature - The temperature of the billet during rolling depends upon the temperature at which it was preheated prior to rolling, time of preheat, and heat transfer considerations during rolling. The actual temperature of the billet during rolling is a complex function of such factors as how long it is out of the furnace before it contacts the rolls, how many passes are made prior to reheating, and the amount of energy input during rolling. This is obviously a very difficult variable to control. We control it as nearly as possible by regulating the temperature of the rolling furnace, imposing reheat periods at various stages in the rolling schedule, and specifying the time the billet remains in the reheat furnace (too long and grain growth becomes excessive, too short and the billet does not reach a suitable temperature). Therefore, in effect, this one variable becomes three: temperature of pre-heating, frequency of preheating, and duration of pre-heating.

2. Rolling Reduction - This variable actually has two aspects - the reduction per pass and the total reduction achieved. We can exert excellent control over both of these variables. 
3. Rolling Direction - This refers to the orientation of the billet as it enters the mill.

Other Variables - Such things as input cast structure, billet geometry, number of billets processed per time, lubrication, and roll condition are all valid and important variables. However, the intent of this section of the report is to concentrate on the three major variables listed above.

c. Measures

1. Sheet Quality - The sheet is examined upon desheathing and etching to look for parallel cracks from rolling, edge cracks from shearing, and surface defects such as protrusions of large grains or bonding of foreign material to the surface. Examples of these defects are given in Figures 4 through 8. Mere presence

Figure 4. Macrophotograph of 0.350 -in. Thick Ingot-Sheet Showing a Large Grain Protrusion in the Surface (left). Foreign material bonded to the surface is evident at the right.

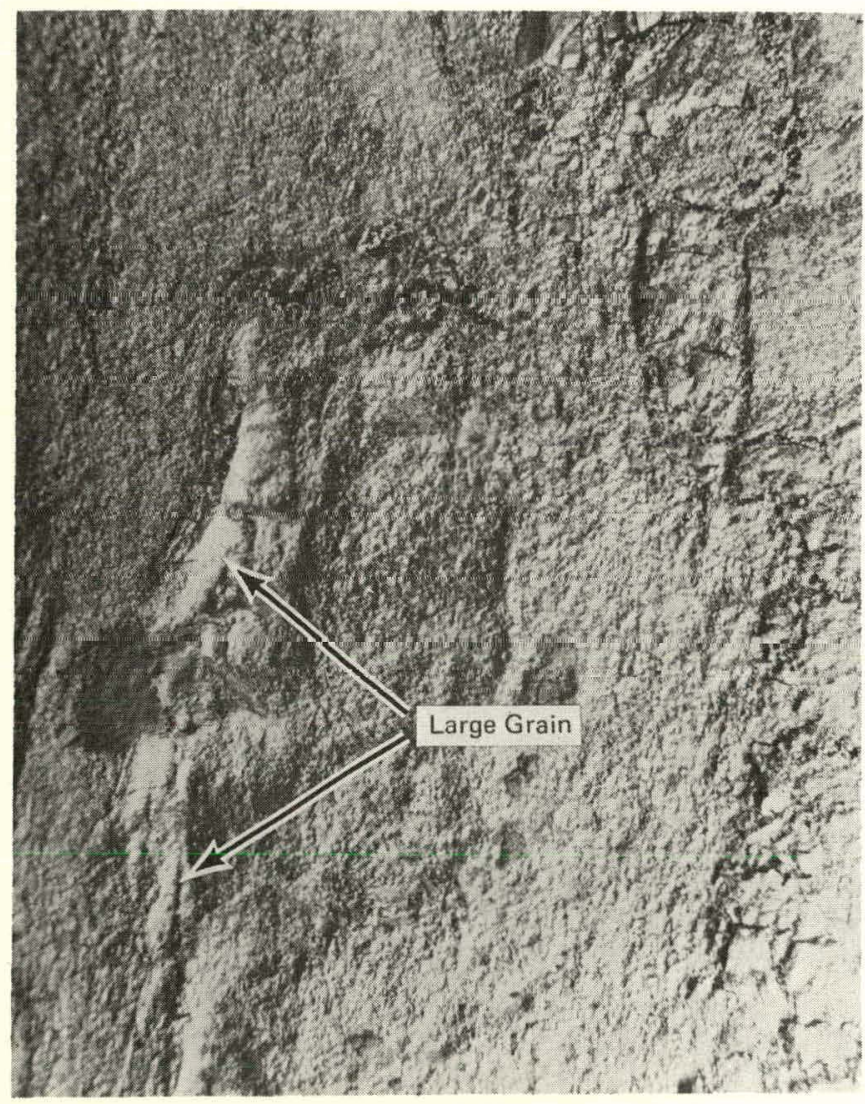

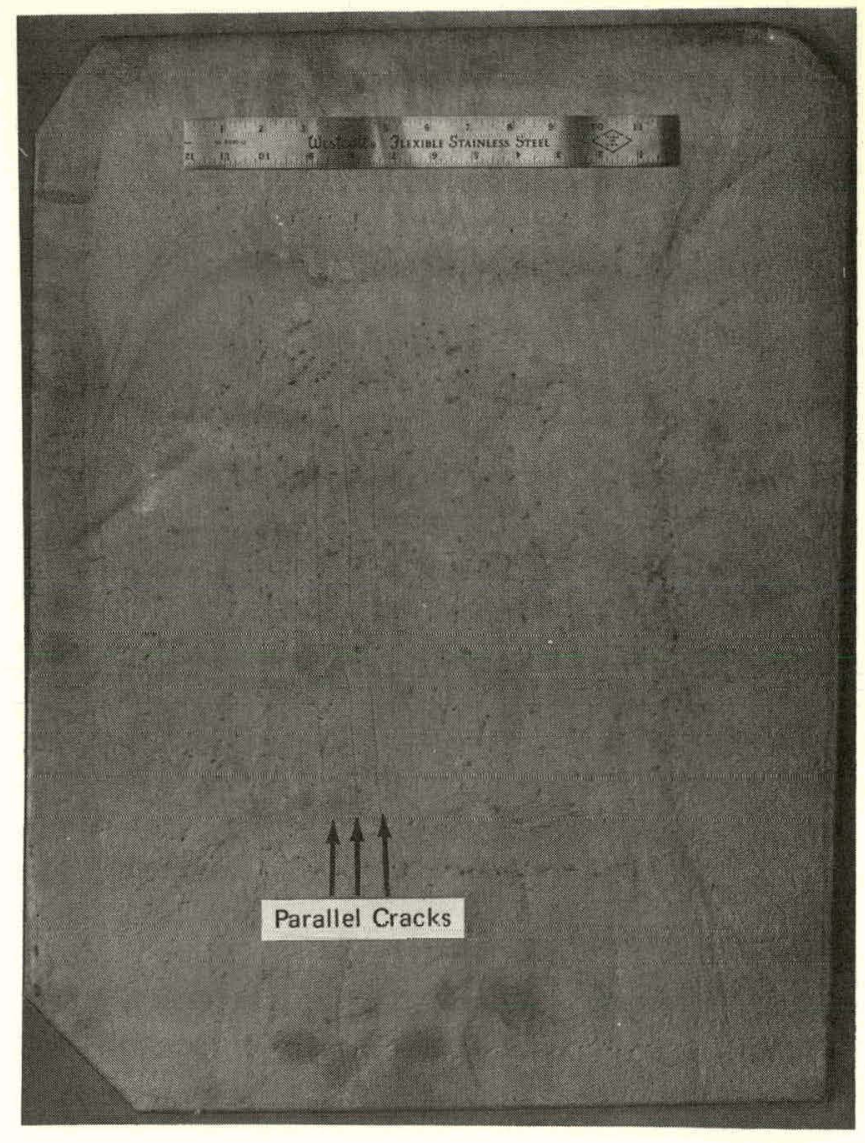

14747-4

Figure 5. Ingot-Sheet, 0.350-in. Thick, Showing Parallel Cracks Induced in Rolling.

of some of these defects is insufficient evidence that the rolling schedule used is no good. The extent of the defects - how much of a given billet is affected and how many billets are affected - is of more concern.

2. Grain Size - We look for average grain size and the single largest grain in a given sample. Orientations both longitudinal and transverse to the rolling direction are examined.

3. Mechanical Properties - In addition to achieving certain minimums, we are concerned about the ratio of longitudinal-to-transverse properties in the plane of the sheet.

4. Product Yield - Ultimately, the most crucial test is how much of the material can be processed through subsequent metal working and machining operations and yield a sound product. 


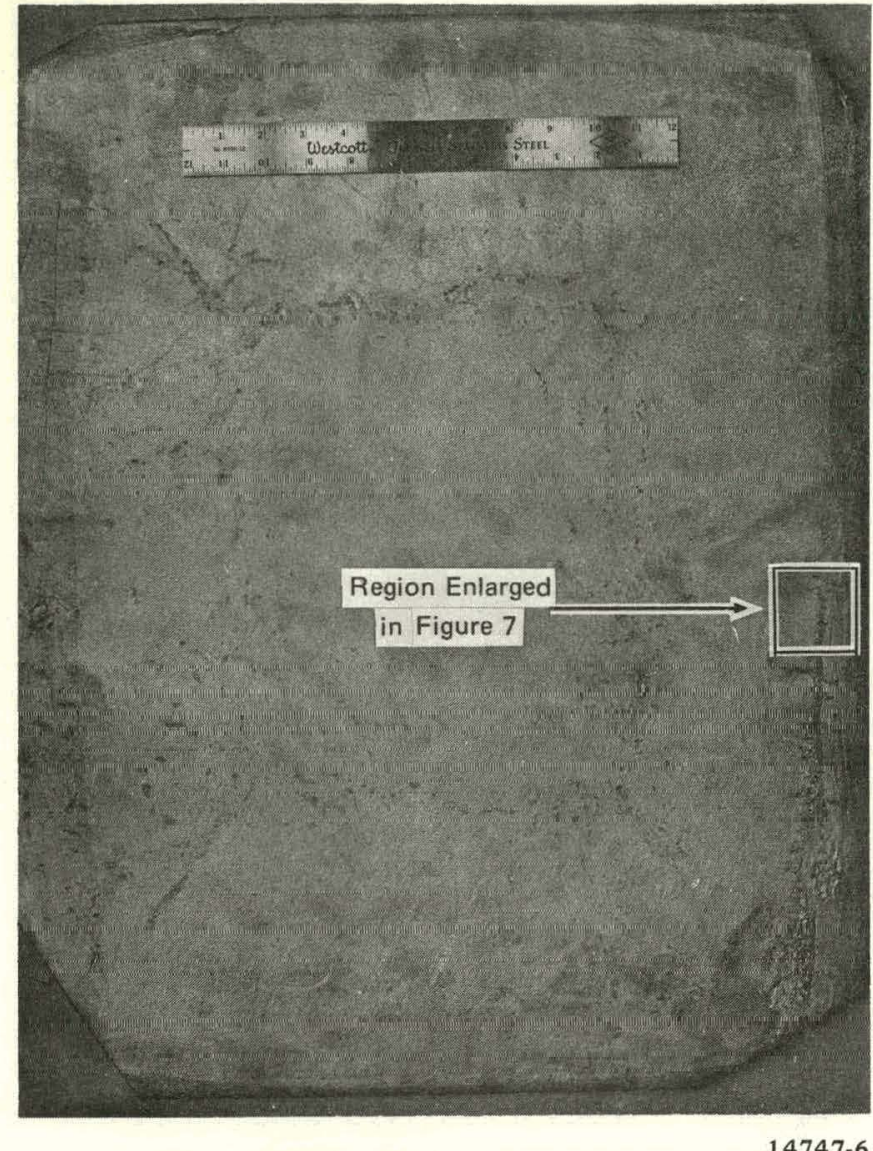

Figure 6. Ingot-Sheet, 0.350 -in. Thick, Showing Foreign Material Bonded to the Sheet Surface. Note that the bonding in the center forms a rectangular pattern. This pattern often intersects diagonal lines from each corner and is called ingotism because it results from planes where columnar grains of the original ingot intersected during solidification.

Much of the material that will be included in this section was not subjected to each of these measures because the section emphasizes those parts of our learning curve that were "blind alleys." Materials produced in such experiments are seldom processed into finished components.

As discussed above, the three major variables which exert control over this complex process are rolling temperature, rolling reduction, and rolling direction. The experiments discussed in this section are grouped accordingly.

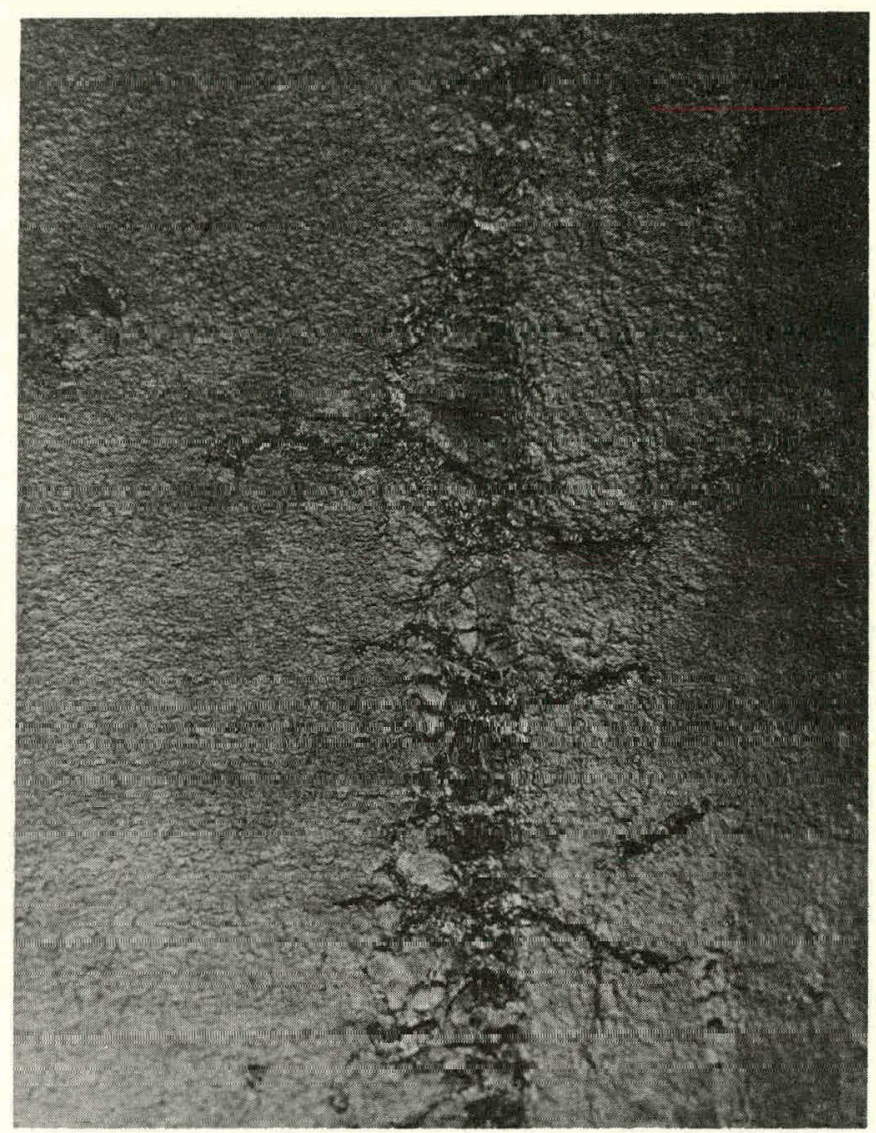

14747-3

Figure 7. Photomacrograph Showing a Region of Surface of the Ingot in Figure 6. The foreign material is part of the 304 stainless steel can which has bonded into a defect in the sheet during rolling. $3 \mathrm{X}$

\section{Rolling Temperature}

The normal sequence of rolling calls for us to load the billets (usually 4 ) into the rolling furnace about 8 to 10 hours prior to the first pass. The furnace is normally at $1900^{\circ} \mathrm{F}$ at this time. Although the data are somewhat limited, soaking periods of less than 4 hours or more that 16 hours have been associated with subsequent rolling problems. The purpose of this soaking period is to put the iron impurities into solid solution. Then, during subsequent rolling at lower temperatures, the iron precipitates, principally as the ternary phase $\mathrm{AlFeBe}_{4} \cdot{ }^{2}$ This ties up the aluminum and prevents hot shortness in subsequent metal working operations. Undoubtedly, the $1900^{\circ} \mathrm{F}$ soak causes the 

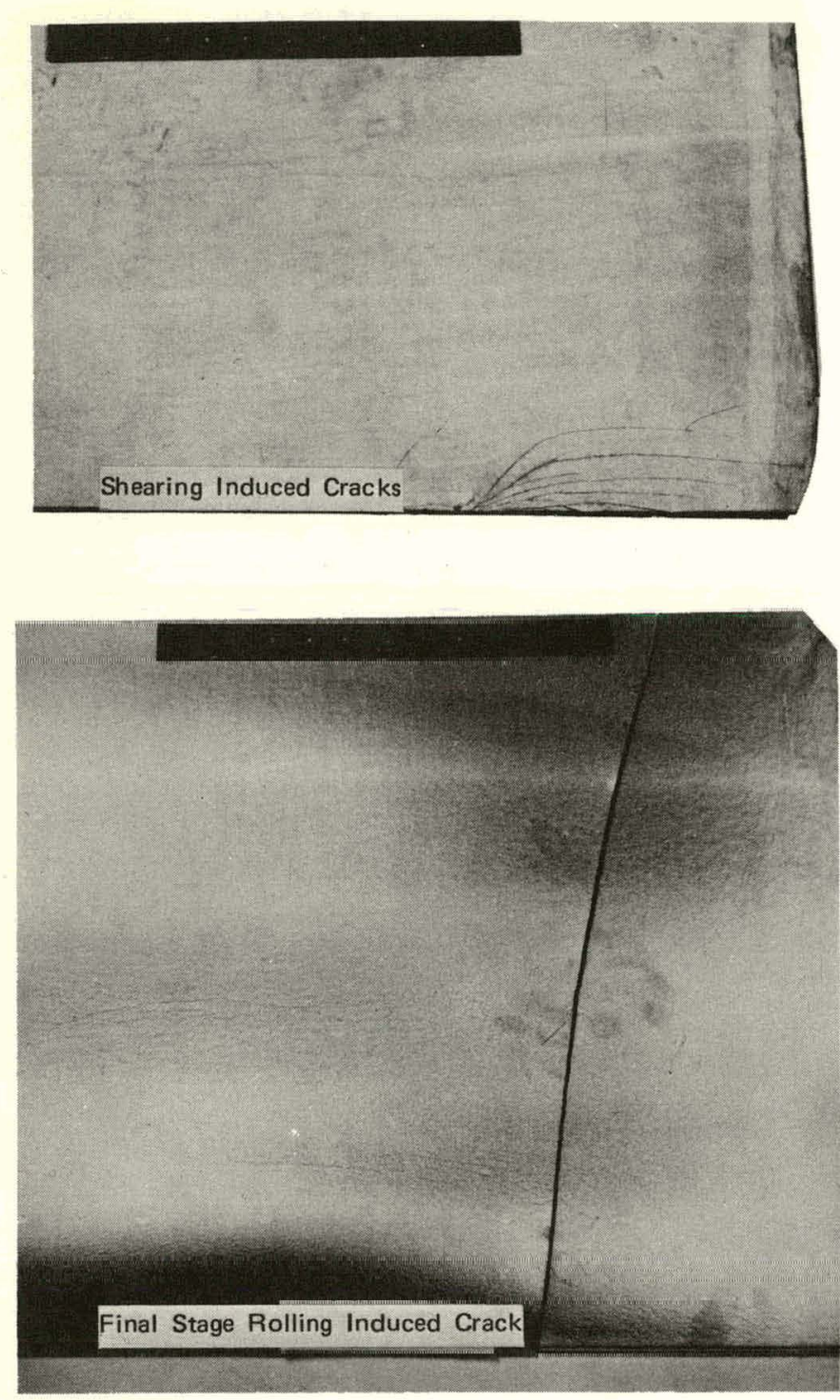

Figure 8. Cracks Which are Present When the Ingot-Sheet is Sheared and Removed from the Can. Occasionally these cracks occur during shearing, but more often they happen in the grain-refinement stage of rolling.

aluminum and silicon impurities to be present as liquid grain boundary phases when rolling commences. Reasons for the problems with both short- and long-soak times are obscure; although they may involve a reaction of the $\mathrm{Al}_{2} \mathrm{O}_{3}-\mathrm{NaSiO}_{3}$ billet coating with the can or the billet.
A solutionizing temperature of $1800^{\circ} \mathrm{F}$ was in use for a long period when no requirements for grain size and mechanical strength were specified. Once such requirements were imposed, the occasional large grains encountered in the 0.2 -in.-thick sheet had to be eliminated. These grains often manifest themselves as bumps on the surface of the sheet, as shown in Figure 4. Apparently these are remnants of the original columnar grains which have not been converted to equiaxed grains. A photomicrograph of a typical large grain in a 0.2 -in.-thick sheet is shown in Figure 9a. Subsequent bare-rolling of material containing such grains merely flattens them out as shown in Figure 9b. These flattened grains can be as large as a half-dollar coin and obviously are deleterious to mechanical properties.

Work reported previously discusses the importance of sufficient deformation at high temperatures to completely break up the cast structure. ${ }^{1}$ We felt that the large grains were due to the material cooling too much during this hot break-down stage of rolling. There are two obvious ways to ensure that the metal is adequately hot in this stage: use higher preheat temperatures, and use fewer rolling passes between reheats. Therefore three changes were instituted as follows:

1. Increased the solutionizing temperature from $1800^{\circ} \mathrm{F}$ to $1900^{\circ} \mathrm{F}$.

2. Changed the sequence of the first eleven passes from 6-5 to 4-4-3, thereby providing an additional $1800^{\circ} \mathrm{F}$ reheat.

3. Extended the hot working range through pass 13 by increasing the preheat temperature from $1600^{\circ} \mathrm{F}$ to $1800^{\circ} \mathrm{F}$ after pass 11 .

These changes were effective in conpletely eliminating the problem with retained cast structure. Experimentation was performed to determine which of the three changes was most significant in eliminating the large grains. When change No. 1 (above) was implemented alone, large grains were present. When change No. 1 was combined with either change No. 2 or No. 3, the large grains were eliminated. But all three changes were implementer to ensure consistent results. 


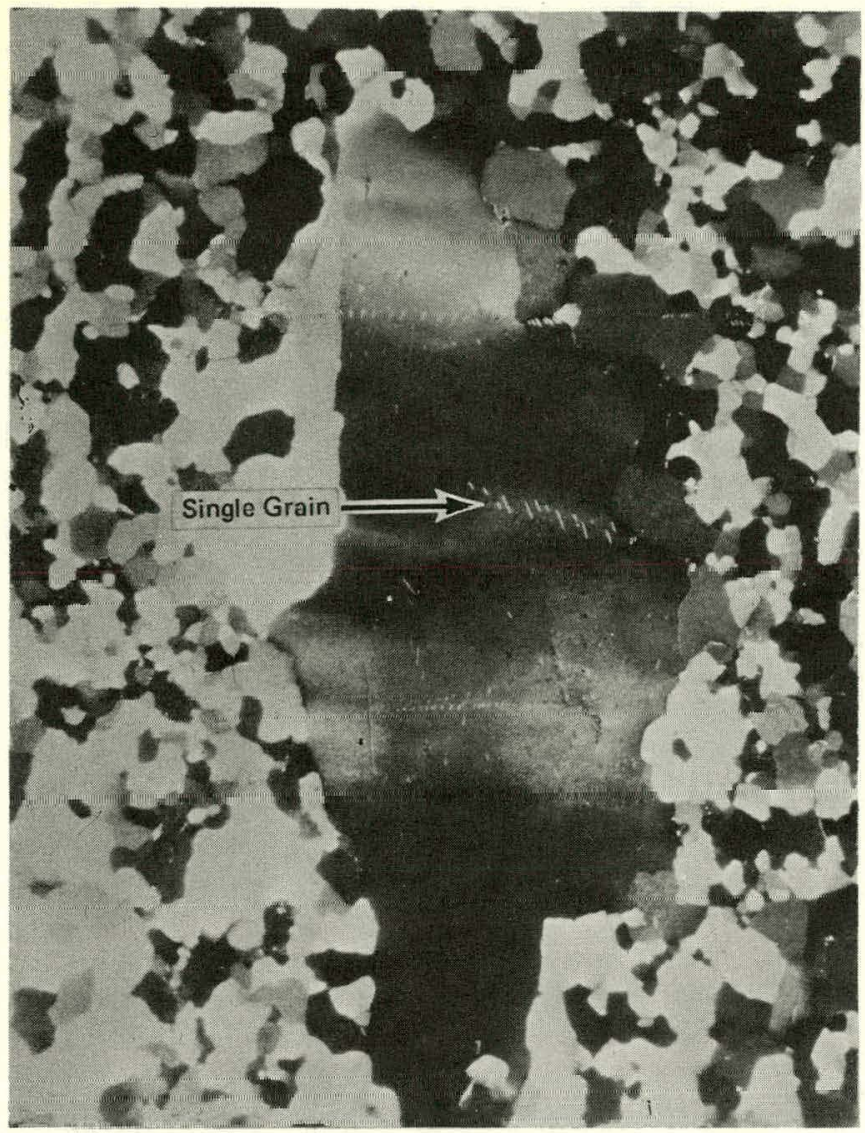

(a)

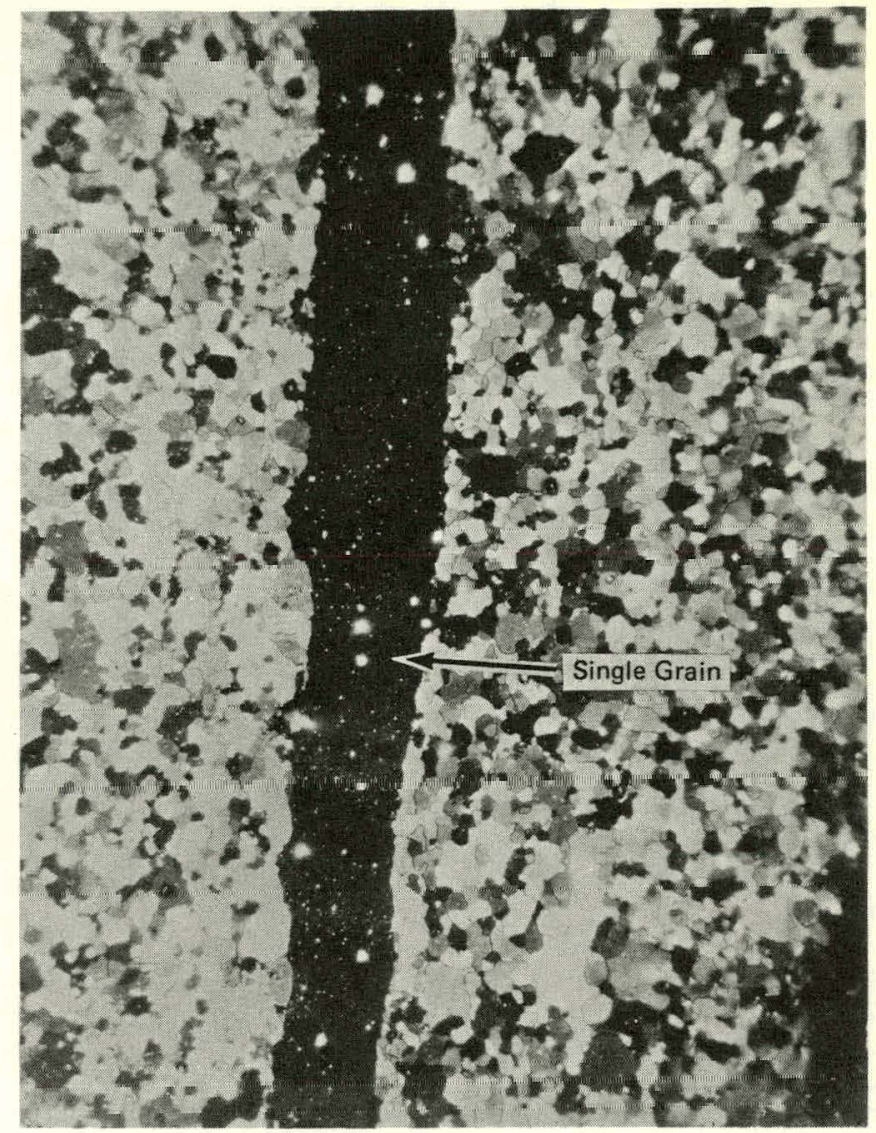

(b)

Figure 9. Polarized-Light Photomicrographs Showing the Presence of (a) Large Grain in a 0.2-in.-thick Ingot Sheet, and (b) a Similar Large Grain that has been Flattened by Rolling the Sheet to 0.100 -in. Thick. 50X

Additional indications of the importance of this hot-working sequence were provided by periodic furnace problems. On one occasion the regular production furnace was out of service and a much smaller furnace was used. The power capacity of the smaller furnace was too low, and the billets did not reach the furnace temperature during reheats. All four sheets had large grains. On another occasion, upon discovering large grains protruding to the surface of several sheets, a check revealed that the thermocouple controlling the preheat furnace was faulty, and we were rolling at temperatures about $100^{\circ} \mathrm{F}$ cooler than we thought. Another time we found bumps in only part of the material rolled. We found that one part of the furnace hearth was cooler than the rest because the furnace element beneath the cooler section had broken. Apparently those billets resting on the cooler part of the hearth were not hot enough during rolling.

Although more examples can be described, the important conclusion of these observations and experiments is that the combined effect of temperature and reduction sequence in hot-breakdown rolling of beryllium is a critical variable that must be closely controlled. We know that the schedule described in Table 3 falls safely within what is apparently a narrow range for this combined variable. Any changes to this rolling schedule, whether by design or accident, must be scrutinized closely to see if they are harmful. 
Since this is a batch operation and critically dependent on temperature, the rolling crew plays an important role in its success. Excessive delays in getting the materials to the rolling mill and back into the furnace can be harmful. In the hotbreakdown range, delays prior to rolling may result in large grains because the sheet is too cold while being worked. Also, delays in getting billets back into the furnace subsequent to rolling will allow the billets to cool so much that the standard reheat time will not be sufficient to bring them to the designated temperature for the next pass. And in the final stages, delays can cause cracking because the cladding will contract and bend the sheet.

As can be seen in Table 3, an intermediate rolling stage is used where the temperatures are intermediate between the $1800^{\circ} \mathrm{F}-1900^{\circ} \mathrm{F}$ hotbreakdown temperature range and the $1400^{\circ} \mathrm{F}$ grain refinement temperature. We do not go directly to $1400^{\circ} \mathrm{F}$ after pass 13 because the stainless steel would work-harden and crack before pass 21. Several experiments have shown that a maximum of four passes at $1400^{\circ} \mathrm{F}$ and reductions of about $20 \%$ each is tolerable.
Because the importance of the hot-working range has been emphasized, it might seem reasonable to extend this range to all but the last four passes. This was trled with a series of für billets and proved unsuccessful. All the material processed was lost for a number of reasons: parallel rolling cracks, shear cracking, unusually rough as-can-rolled surfaces, and bare-rolling cracks. The microstructure at the 0.2-in. can-rolled thickness was also inferior to that produced by following the schedule in Table 3. The average grain size of the material rolled at $1800^{\circ} \mathrm{F}$ through pass 17 ranged from 56 microns to 120 microns, compared to a range of 50 to 60 microns for the normal product at 0.200-in. thickness. A comparison of the microstructures of the standard and extensively hotrolled materials, after each has been bare-rolled to 0.100-in. thickness, is given in Figure 10.

In view of these facts, an intermediate rolling stage is necessary. Its purpose is twofold: (1) to provide some grain refinement without cold-working the stainless steel can, and (2) to gradually transfer the rolling temperature from the hot-working to the grain-refinement stage.

Figure 10. Comparison of Standard (a) and Extensively Hot-Rolled (b) Beryllium-Ingot-Sheet Materials at 0.1-in. Thickness: Grain Sizes are 33 Microns and 51 Microns, Kespectively. Polarized Lighı. 50X

(a) Standard

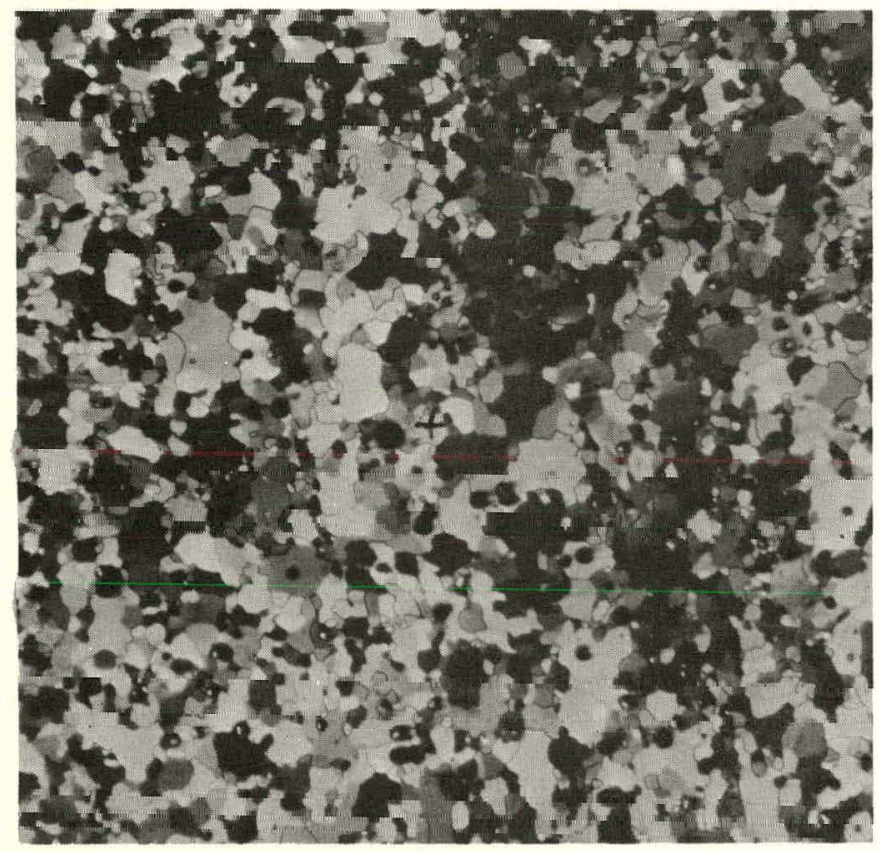

(b) Hot-Rolled

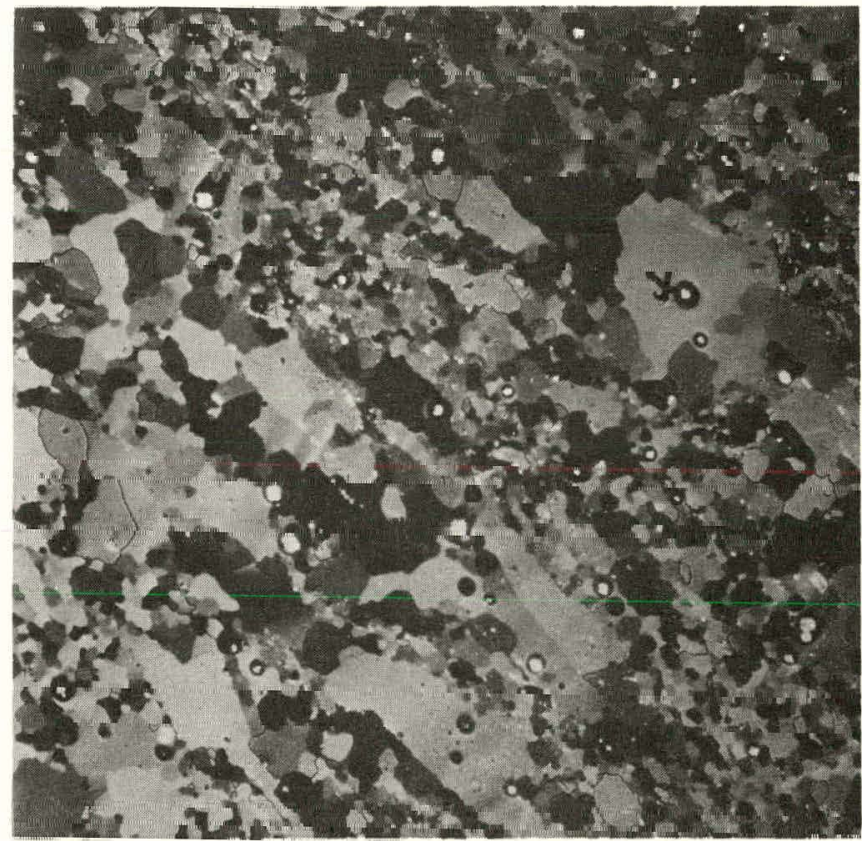


A radical departure from the hot-breakdown scheme has shown promise. Instead of beginning the rolling operation at $1900^{\circ} \mathrm{F}$, four billets were given the first six passes at $1400^{\circ} \mathrm{F}$. Two of these hillets were stored at $1100^{n} \mathrm{~F}$ for 3 hours whlle the remainıng two were heated to $1800^{\circ} \mathrm{F}$. The concept was to cold work the as-cast material, providing many more nucleation sites for new grains than the normal $1900^{\circ} \mathrm{F}$ hot working causes. Then reheating to $1800^{\circ} \mathrm{F}$ removes most of the cold work in the stainless can and encourages nucleation and growth of an equiaxed structure. The remaining rollung passes of the lirst two billets were done according to the schedule in Table 3 , exccpt that the reheat after pass 8 was omitted. The can remained intact and the sheet was sound. The other two billets were given five additional passes at $1400^{\circ} \mathrm{F}$. One can failed; but the other survived and was heated to $1800^{\circ} \mathrm{F}$ and rolled according to the schedule in Table 3 for passes 12 through 21 . The can held and the sheet was sound. All this material was successfully bare rolled to 0.100 inch. The microstructure of the material given eleven passes at $1400^{\circ} \mathrm{F}$ proved uniform and equiaxed with a grain size of 40 microns as shown in Figure 11. However, some retained cast structure was evident in one of the two sheets given only six passes at $1400^{\circ} \mathrm{F}$, as shown in Figure 12. The mechanical properties of these materials are compared to the average values for the standard materials in Table 4. A slight improvement is noter in the material cold worked at $1400^{\circ} \mathrm{F}$ prior to rolling. I his approach was set aside because of the apparent need for eleven passes at $1400^{\circ} \mathrm{F}$ to completely eliminate the cast structure. The stainless steel ran muld not be expected to survive this amount of cold work on a production basis. The more uniform structure and slight improvement of mechanical properties did not warrant pursuing alternative sanning materials.

Numerous experiments have been done to optimize the rolling temperature in the grain refinement stage. The competing factors in this optimization are the reduction in grain size resulting from lower rolling temperatures versus the loss in ductility of the stainless steel can at these lower tempcratures. Early on we finished our can-rolling with two passes at $1500^{\circ} \mathrm{F}$ and two at $1450^{\circ} \mathrm{F}$. This was later adjusted to two passes at $1450^{\circ} \mathrm{F}$ and two at

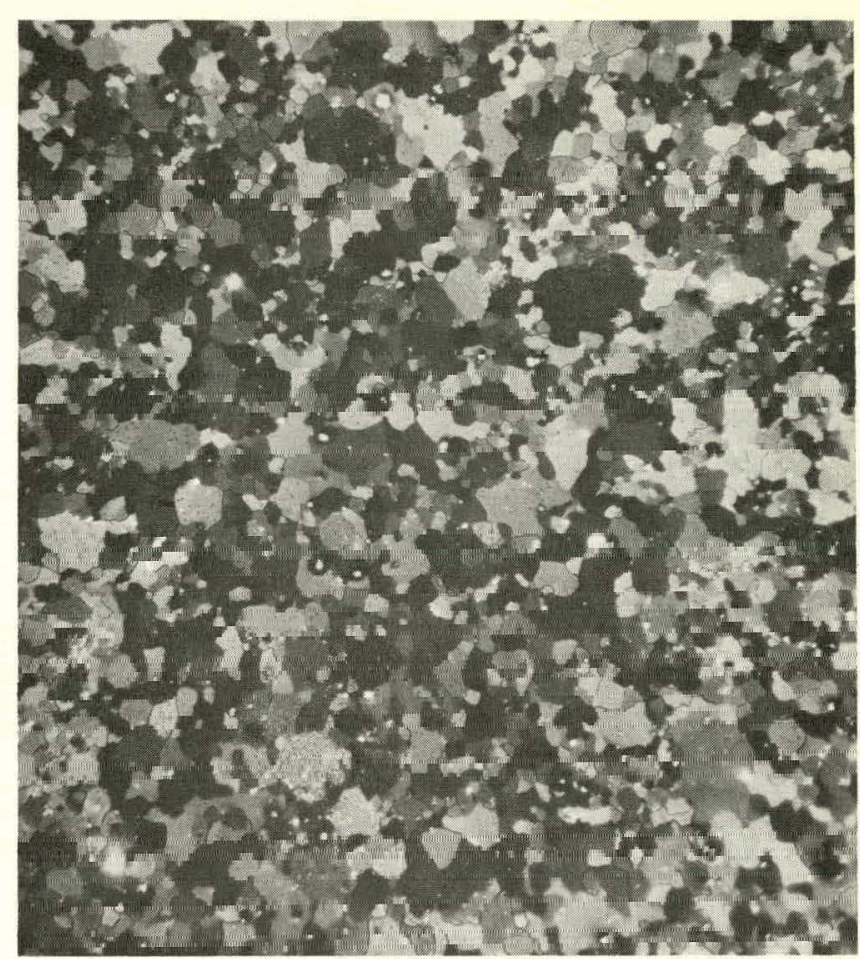

Figure 11. Photomicrograph of 0.1-in.-thick Ingot-Sheet Material that has been given by Eleven Passes at $1400^{\circ} \mathrm{F}$. Polarized light. $50 \mathrm{X}$

Figure 12. Photomicrograph of 0.1-in.-thick Ingot-Sheet Material Given Six Passes at $1400^{\circ} \mathrm{F}$ Prior to Hot Rolling. Polarized light. 50X

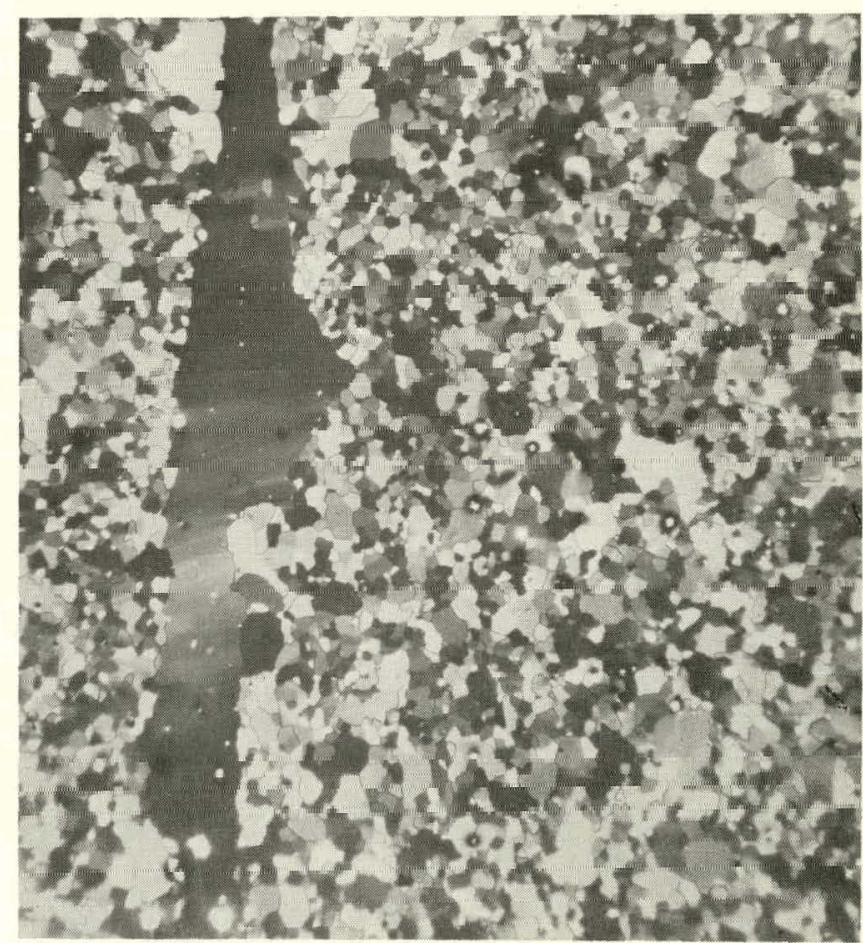


Table 4. Comparison of Tensile Properties of Standard Material and Material Rolled at $1400^{\circ} \mathrm{F}$ Prior to the Hot Breakdown.

\begin{tabular}{|c|c|c|c|c|c|}
\hline $\begin{array}{l}\text { Material } \\
\text { Type }\end{array}$ & $\begin{array}{c}\text { Test } \\
\text { Direction }\end{array}$ & $\begin{array}{l}\text { No. } \\
\text { Tests }\end{array}$ & $\begin{array}{l}\text { Ultimate } \\
\text { (ksi) }\end{array}$ & $\begin{array}{c}0.2 \% \\
\text { Offset } \\
\text { Yield } \\
\text { (ksi) }\end{array}$ & $\begin{array}{c}\text { Elongation } \\
(\%)\end{array}$ \\
\hline Standard & Longitudinal & $\sim 3000$ & 49.7 & 26.1 & 6.2 \\
\hline Standard & Transverse & $\sim 3000$ & 43.7 & 26.0 & 4.9 \\
\hline $\begin{array}{l}\text { Rolled at } \\
1400^{\circ} \mathrm{F}\end{array}$ & Longitudinal & 9 & 54.0 & 28.0 & 7.0 \\
\hline $\begin{array}{l}\text { Rolled at } \\
1400^{\circ} \mathrm{F}\end{array}$ & Transverse & 9 & 49.0 & 28.0 & 6.0 \\
\hline
\end{tabular}

$1400^{\circ} \mathrm{F}$, and finally all four at $1400^{\circ} \mathrm{F}$. The average grain size improved from about 100 microns to the 50 to 60 -micron range currently obtained. Attempts at using $1350^{\circ} \mathrm{F}$ and $1300^{\circ} \mathrm{F}$ for the final two passes resulted in 50-micron average grain sizes, but about one-half of the cans cracked.

\section{Rolling Reduction}

As is evident in Table 3, our standard schedule calls for light reductions ( $\sim 10 \%$ per pass) in the hot-working stage, moderate reductions $(\sim 15 \%$ per pass) in the intermediate stage, and heavy reductions $(\sim 20 \%)$ in the grain-refinement stage of rolling. The rolling mill is capable of heavy reductions in the hot-breakdown stage and some work has been done in this area. One experiment consolidated the first eleven passes into five passes, each about $20 \%$ reduction. The normal schedule was followed for passes 12 through 21 . This material was comparable to material processed by the standard cycle. When the experiment was repeated on another occasion, the mill would not "bite" the billets on the first pass. The reason was that a new set of work-rolls with a smoother surface finish than those used previously had been installed. Also, the rolls were at room temperature, having been cooled over a weekend. (The heat induced from rolling hot materials usually maintains the rolls at a temperature of about $120^{\circ} \mathrm{F}$.) And finally there was such an excess of lubricant on the rolls that even the normal $6 \%$ reduction for the first pass could not be achieved without first wiping the rolls clean. The billets were finally rolled, but the delays causcd them to cool to such an extent that normal reheat times were inadequate and the resulting sheet was replete with large grains. Our conclusion was that the advantage of saving some time by the heavy initial reductions was not worth the risk of delays caused by the rolls not accepting the billets on the first pass.

The rolling reductions in the intermediate stage do not tax the capacity of the rolling mill. An experiment was run whereby the first eight passes were the same as the standard schedule (Table 3), hut the next nine passes were consolidated into three $30 \%$ reductions. Intermediate reheats of $1800^{\circ} \mathrm{F}$, $1600^{\circ} \mathrm{F}$, and $1500^{\circ} \mathrm{F}$ were used after these heavy reductions, and the standard schedule was used for the final four passes. There were two reasons for this experiment:

1. The heavy reductions, by putting more deformation into the structure at one time, might promote more grain refinement in this stage.

2. The curling of the billets normally experienced in passes 12 through 15 ('Table 3 ) might be eliminated by the heavier reductions.

Sixteen billets were processed in this manner. Although curling was eliminated, the desired improvement in the microstructure did not materialize. Mechanical properties were comparable to material rolled by the standard schedule. The average grain size was also the same as in material made with the standard practice, but some retained cast structure was found metallographically in fractured surfaces of tensile bars, and on machined surfaces. This further emphasizes the sensitivity of the hotbreakdown stage in Table 3. This experiment covered part of that stage and all the intermediate stages. Consolidation of the four passes of the intermediate stage into two passes might seem a logical follow-up experiment, but the curling problem is more severe in passes 12 and 13 so this whole approach has been abandoned.

The reductions used in the last four passes could not be much heavier without exceeding the 
$5,000,000 \mathrm{lb}$ separating force capability of the mill. Several factors contribute to this; such as, the width of the sheet is large ( 230 in.), the stainless steel is cold worked, and the stress required to deform the sheet is high because of the high stress state found with large ratios of roll diameter-tosheet thickness. ${ }^{3}$ Some work has been done using lighter reductions. Reductions between $10 \%$ and $20 \%$ per pass have about the same effect on resulting grain size and properties as do the $20 \%$ reductions, providing that more passes are used so that the cumulative reduction is the same. Reductions of less than $10 \%$ are avoided because the sheet does not reduce uniformly through its thickness, and therefore serious curling results. If the mill operator misses the final gauge and sends the sheet back through for a final "skin-pass," experience has shown that the sheet will develop a radius of curvature as tight as 10 inches.

\section{Rolling Direction}

A subject closely related to rolling reduction is rolling direction. This refers to the orientation of the sheet being rolled relative to the rolls. The rolling direction is defined as the horizontal direction that is perpendicular to the roll axes. We are concerned about the relative magnitude of the mechanical properties of the sheet in directions longitudinal (parallel) and transverse (perpendicular) to the rolling direction. Ideally, there would be no difference between the properties in the two directions. The way to achieve the ideal condition is to rotate the rolling billets $90^{\circ}$ after each pass, using the same rolling temperature and reduction for each pair of passes. We can follow this practice until the sheet reaches about 30 in. by 30 in., whereupon we must roll in one direction or the sheet will be too wide for our rolling furnace. In the standard schedule, this 30 -in. square is present after pass 17. The mechanical properties shown in Table 5 for 0.2-in. thick can-rolled material show that this unidirectional rolling renders the mechanical properties in the longitudinal direction superior to those in the transverse direction. But if bare rolling is done in a direction $90^{\circ}$ to the final canrolling direction, then the desired balance can be obtained. The data in Table 5 show that this balance is achieved at 0.125 -in. sheet thickness,
Table 5. Room Temperature Tensile Properties of Standard Material at Three Different Thicknesses Showing the Change in Properties that Occurs in Bare Rolling.

\begin{tabular}{|c|c|c|c|c|c|}
\hline $\begin{array}{l}\text { Sheet } \\
\text { Thickness } \\
\text { (in.) }\end{array}$ & $\begin{array}{l}\text { Amount of } \\
\text { Reduction } \\
\text { by Bare } \\
\text { Rolling (\%) }\end{array}$ & $\begin{array}{c}\text { Test } \\
\text { Direction* }\end{array}$ & $\begin{array}{l}\text { Ultimate } \\
\text { (ksi) }\end{array}$ & $\begin{array}{l}0.2 \% \\
\text { Offset } \\
\text { Yield } \\
(\mathrm{ksi})\end{array}$ & $\begin{array}{c}\text { Elongation } \\
(\%)\end{array}$ \\
\hline \multirow[t]{2}{*}{0.2} & 0 & L & 42.4 & 25.6 & 2.7 \\
\hline & & $\mathrm{T}$ & 30.2 & 24.8 & 1.9 \\
\hline \multirow[t]{2}{*}{0.125} & 38 & L & 43.0 & 25.0 & 5.0 \\
\hline & & $\mathrm{T}$ & 43.0 & 25.0 & 5.0 \\
\hline \multirow[t]{2}{*}{0.100} & 50 & L & 49.7 & 26.1 & 6.2 \\
\hline & & $\mathrm{T}$ & 43.7 & 26.0 & 4.9 \\
\hline
\end{tabular}

*These are longitudinal (L) and transverse (T) to the barerolling direction, which is $90^{\circ}$ to the rolling direction for the last four can-rolling passes.

and rolling to 0.100 -in. thick causes the properties in the last bare-rolling direction to be superior. We are, however, concerned principally with the yield stress, which is well-balanced between the two directions at 0.100 -in. thickness.

We have discovered through numerous unplanned production experiments that mixing the cross-rolling sequence during the hot-breakdown stage does not affect the isotropy of the resulting sheet. In other words, if the mill operator accidentally turns the billet $180^{\circ}$ and runs it through the mill in the same direction twice, he can compensate by running the next two passes in a direction transverse to the previous two. However, in a controlled experiment with four billets, we found that unidirectionally rolling in passes 7 through 13 followed by turning $90^{\circ}$ and unidirectionally rolling passes 13 through 21 is unacceptable. The microstructure was banded rather than equiaxed and the sheet quality was inferior to standard material.

Another important factor related to unidirectional rolling is the concern about which end of the sheet enters the rolls first. The leading edge often bends around the bottom roll and into the stripper bar on each of the last four passes. If the same end enters first each time, the flexing may cause the can to crack open. To prevent this, we flip the billet upside down and turn it end-for-end after each of 
the last four passes. As mentioned above, this must be done with haste because the can will contract and crack the beryllium if it is out of the furnace more than 75 seconds. Also, after turning the sheet, it must not be dropped onto the roll table because, despite being at an elevated temperature, the beryllium is very brittle after just receiving a $20 \%$ rolling reduction.

\section{PROBLEMS IN CAN-ROLLING}

Although the rolling schedule that resulted from the development work described above will produce sound sheet, we still encounter problems periodically in can-rolling. It is not unusual to obtain a can-rolling efficiency of $99 \%$ for a run of one- or two-hundred billets and then lose four out of the next twelve billets rolled. Consequently we have done a good deal of trouble shooting. This section of the report describes the problems that cause the losses, and discusses the variables that are responsible for these problems.

\section{Causes of Rolling Problems}

The major problem in can-rolling beryllium is curling of the sheet that occurs in the thickness range of 0.75 to 1.5 inches. This corresponds to passes 11 to 15 in the standard rolling schedule (Table 3 ). Curling is not always harmful, but it can result in the stainless steel can splitting open in subsequent passes. In fact, our most frequent can-rolling loss occurs when an upward curl develops on pass 14 , the billet is rotated $90^{\circ}$ and the curl is flattened out in pass 15. During pass 15 the side that had been the leading edge in pass 14 splits open as shown in Figure 13. The crack is normally about 1.5- to 2-in. inward from the side of the billet, putting it near the location of the weld root or underbead. The cross-section of an actual billet that failed in this mode is given in Figure 14. It shows that the failure is not at the weld root but a short distance further inward. It appears to be a ductile failure caused by excessive strain resulting from curling and subsequent flattening. Notice that the bottom cover plate (Figure 14) is much thicker than the top cover plate. This suggests that the ductility of the top cover plate was simply

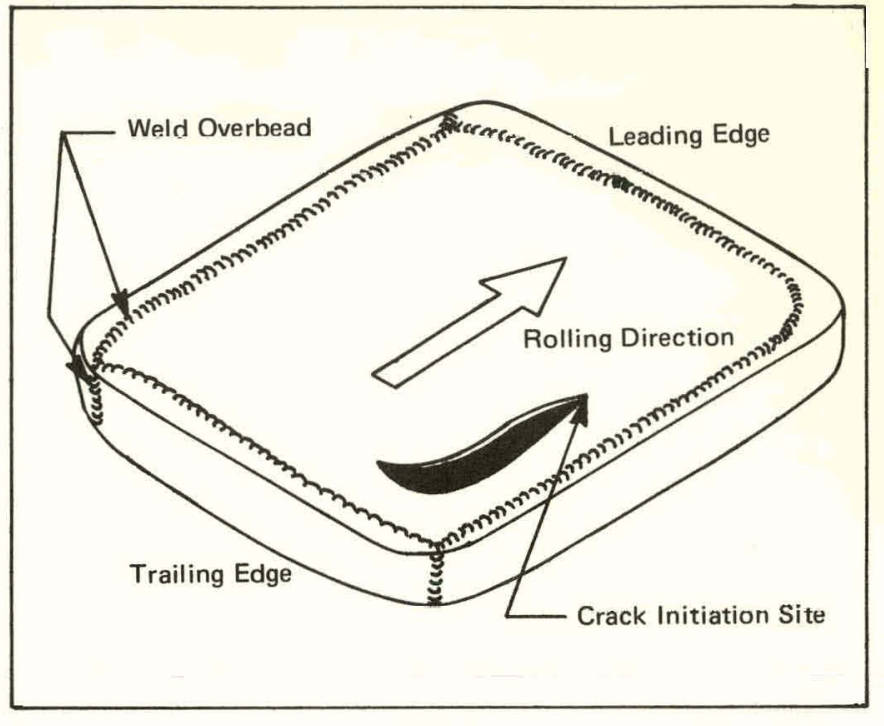

Figure 13. Location of the Crack in a Typical 15th Pass Failure.

exhausted by thinning under a tensile loading just prior to failure.

Curling in passes 11 to 15 can cause other kinds of problems. The can may remain intact while the beryllium sheet within is badly cracked. Once started, curling may continuc in each pass and the can might finally split open in the final few passes. Delays caused by trying to feed curled billets into the rolls often cause excessive cooling of the billets and thereby promote cracking of the beryllium.

Another frequent problem is can failure through the original side plate. Notice the sharp crack in the center of the steel in Figure 14. This crack results from the side plate bending over on itself during hot-breakdown rolling and being tightly crimped during the intermediate rolling stage. As long as the crack remains in a plane parallel to the top and bottom surfaces of the billet, the can will not fail. But if the crack turns and propagates toward one of these surfaces, as shown in Figure 15, the can may rupture during the final rolling stage. It is possible to continue rolling a billet containing such a crack so long as the end containing the defect is always the trailing edge. This orientation causes the air that enters the can during reheats to be forced out through the crack during rolling. If the crack is situated on the leading edge, the air is compressed into the closed end where it ruptures 


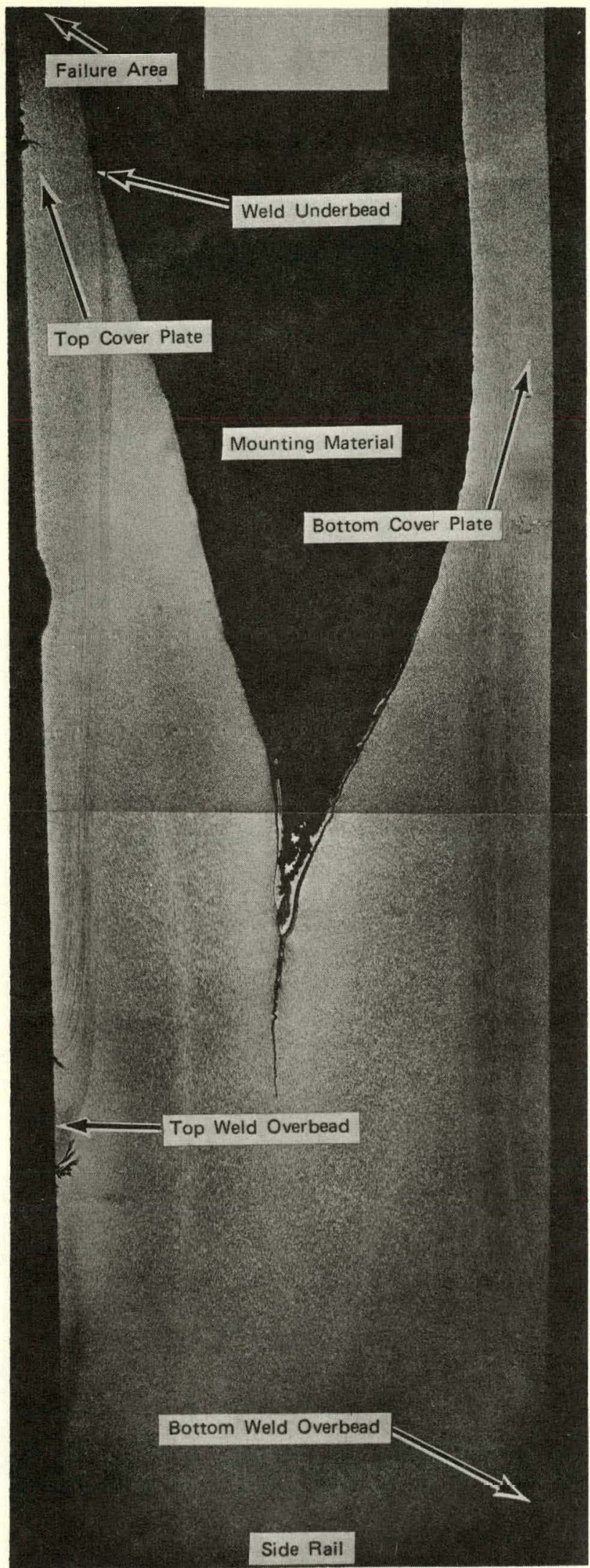

Figure 14. Cross-Section of Typical 15th Pass Failure Taken Through Fracture Area in Figure 13. Billet number 2846B.

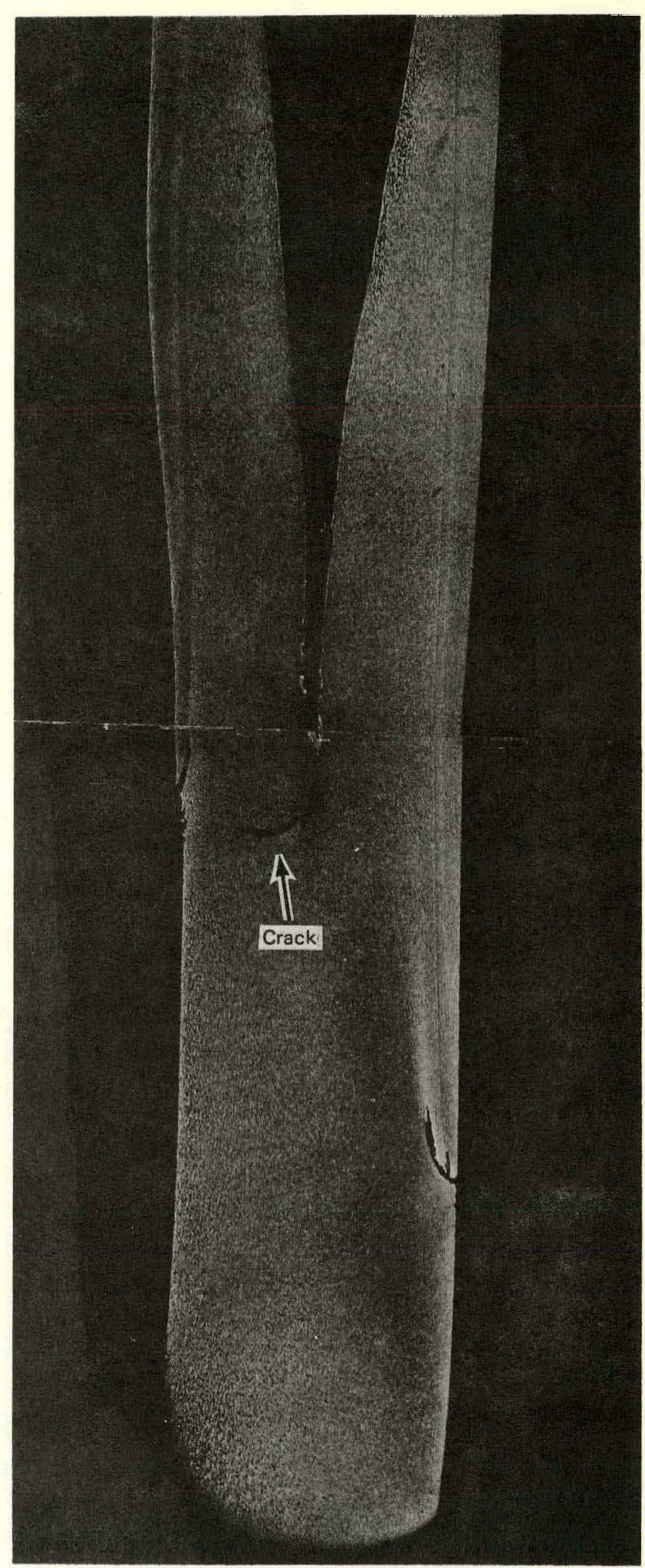

Figure 15. Typical Later-Stage Failure that Occurred on Billet Number 2882-B During Pass 19. Failure resulted when the internal crack shown propagated to the surface. 
the can, endangering personnel. Because of toxicity concerns, we normally cease all rolling operations once the stainless steel can opens. Repairing such defects by heliarc welding has been done, but the repairs frequently fail in subsequent rolling. Also, the sheet produced subsequent to such repairs is inferior to our normal sheet. This type of failure occurs most frequently in billets which have curled in passes 11 through 15 and whose leading edges are flexed back and forth during the final four passes.

\section{Variables Which Affect Can-Rolling Problems}

It is obvious that the variables which influence curling are critical to the success of can rolling. The variables can be separated into three categories: friction variables, external variables, and can variables.

\section{FRICTION VARIABLES}

Curling depends strongly on the coefficient of friction between the work rolls and the billet. Friction, in turn, depends upon the amount of reduction in a given pass, lubricants used, surface finish of rolls and billets, roll temperature, and billet temperature. Since we use a standard rolling schedule, the reductions and temperatures are relatively uniform from day to day. Also, the surface roughness of the rolls and billets is reasonably uniform on a day-to-day basis. Lubrication is the one variable which can be changed easily.

An example of the importance of this friction variable is as follows. Normally our work rolls has been ground to a surface finish of 20- to 30microinches $\mathbf{A A},{ }^{*}$ but on one occasion a set was ground to a 10 to 20 -microinch AA finish. When these rolls were installed, our can-rolling efficiency dropped from $99 \%$ to $77 \%$; most of the losses being the pass 15 can-splitting type. After exploring many possibilities for an explanation to this sudden decrease in efficiency, we eventually installed a new set of work-rolls that had a surface finish of 50 to 60-microinches AA. Only a slight improvement in efficiency resulted. We then put in a set of work-rolls with a 20 to 30 -microinch AA surface

\footnotetext{
*Arithmetic Average of peak to valley distance.
}

finish on the top roll and a 50 to 60 microinch AA surface finish on the bottom roll. The efficiency immediately returned to the $99 \%$ level. When trying to get a production stream back to an efficient operation, it is hard to run controlled experiments-allowing only one variable at a time to vary -to pinpoint the problem. Normally, the approach is to adjust every variable in the direction that will eliminate the problem. But in this case we are reasonably confident that the friction variable is the key to the problem. This confidence is supported by simulation experiments, which were run on a laboratory rolling mill, where only one variable was examined at a time. ${ }^{4}$ These experiments show that the advantage of having the rougher surface on the bottom roll is that the rolling stock tends to curl down. Since the roll table and stripper bar of our production mill will contact the billet as it exits and prevent it from curling down, the net effect is to produce flat billets.

The film of lubricant on the rolls can vary considerably during rolling. We have ceased the spray-mist system of lubrication on our mill in favor of manual methods. Prior to rolling, the rolls are wiped dry using perchlorethylene solvent. No lubricant is used during the first eight passes. Prior to pass 9 a few drops of lubricant* are squirted onto the top back-up roll and spread over the roll surface. The work roll is lubricated only by contact with the back-up roll. The bottom work rull and lack-up roll are never lubricated. The top back-up roll is cleaned and relubricated during each reheat throughout the remainder of the rolling schedule.

The function of the lubricant is two-fold. First, it pievents the build-up of a rust-colored scale on the top work roll. The scale is thought to increase the friction between roll and billet, and therefore is desirable on the bottom work roll. Secondly, the lubricant lowers the friction coefficient between the top work roll and the billet, thereby favoring curling down into the stripper bar rather than up into the air.

\section{EXTERNAL VARIABLES}

This category of variables deals with those circumstances of rolling which are set before the billet

\footnotetext{
*Texaco Type CX, water soluble oil, equal parts of water and oil.
} 
actually enters the rolls. It includes such things as the relative diameters of the top and bottom rolls, the angle of entry of the billet to the rolls, the ratio of roll diameter-to-thickness, roll hardness, crown of the rolls, and relative temperature of the top and bottom of the rolling billet. The effect of such variables on problems encountered in canrolling are discussed below.

There seems to be a critical thickness range where curling problems are encountered. If billets get through that range without curling, then normally they will not curl at a later stage. For a long period the passes corresponding to a 1.3-in. and a 1.1-in. mill setting were considered the critical ones. After increasing the temperature for these two passes from $1600^{\circ} \mathrm{F}$ to $1800^{\circ} \mathrm{F}$, the next two passes became crucial in that curling might start on one of them. The ratio of the roll diameter to the thickness of the work piece $(\mathrm{D} / \mathrm{t})$ seems to be more important than the absolute thickness as regards whether or not curling will occur. We have used a similar rolling schedule to the one in Table 3 on a 2-high mill with 24-in.-diameter rolls without experiencing curling. The $\mathrm{D} / \mathrm{t}$ ratio where we experience problems in our standard schedule is about 12 to 1 . In production rolling, we start with a $D / t$ of $\sim 3$ and end with $D / t$ of $\sim 24$, so we must pass through the critical 12 to 1 ratio. On the 2-high mill we begin with a 12 to 1 ratio and, of course, increase it during rolling by decreasing the thickness. We also find that rolling small billets, having one-quarter the dimensions of standard billets, on a 2-high laboratory mill with 6-in. rolls, we get curling at a $\mathrm{D} / \mathrm{t}$ ratio of about 12 to 1 .

We maintain a difference in diameter between top and bottom work rolls of 0.002-in., the larger being on the bottom. We have had the larger roll on top also, and we detect no significant difference in rolling in either mode. Theoretical considerations and laboratory experiments with much greater differences in roll diameter both show that the larger roll should reside on the top to minimize upward-curling. ${ }^{4}$ If a curl develops, the sheet curls away from the larger roll. This is because the surface speed of the larger roll is greater when both rolls turn at the same revolutions per minute.
Our experience shows that the manner of entry of the billet into the rolls is an important variable. Ideally, the pass-line of the mill table will be adjusted as shown in Figure 16a, so that the midplane of the billet is coplanar with the horizontal plane of symmetry of the rolls. This facilitates an equal reduction through the thickness. We have tried to roll billets when the roll table is fixed at 0.250 -in. below the horizontal tangent to the bottom work roll, giving a condition similar to that shown in Figure 16b. Normally, the back of the billet is simply lifted off the roll table as shown, and no severe curling is experienced if friction conditions are correct. We have also raised the roll table so that the plane of the roll table is tangent to the bottom work roll. This causes a severe problem with upward-curling as shown in Figure 16c. Since, in our standard schedule, reductions vary from 0.3 to 0.040 -in., the ideal

Figure 16. Three Possible Positions of the Roll Table Relative to the Horizontal Plant of Symmetry Between the Rolls. (The drawings are not to scale.)

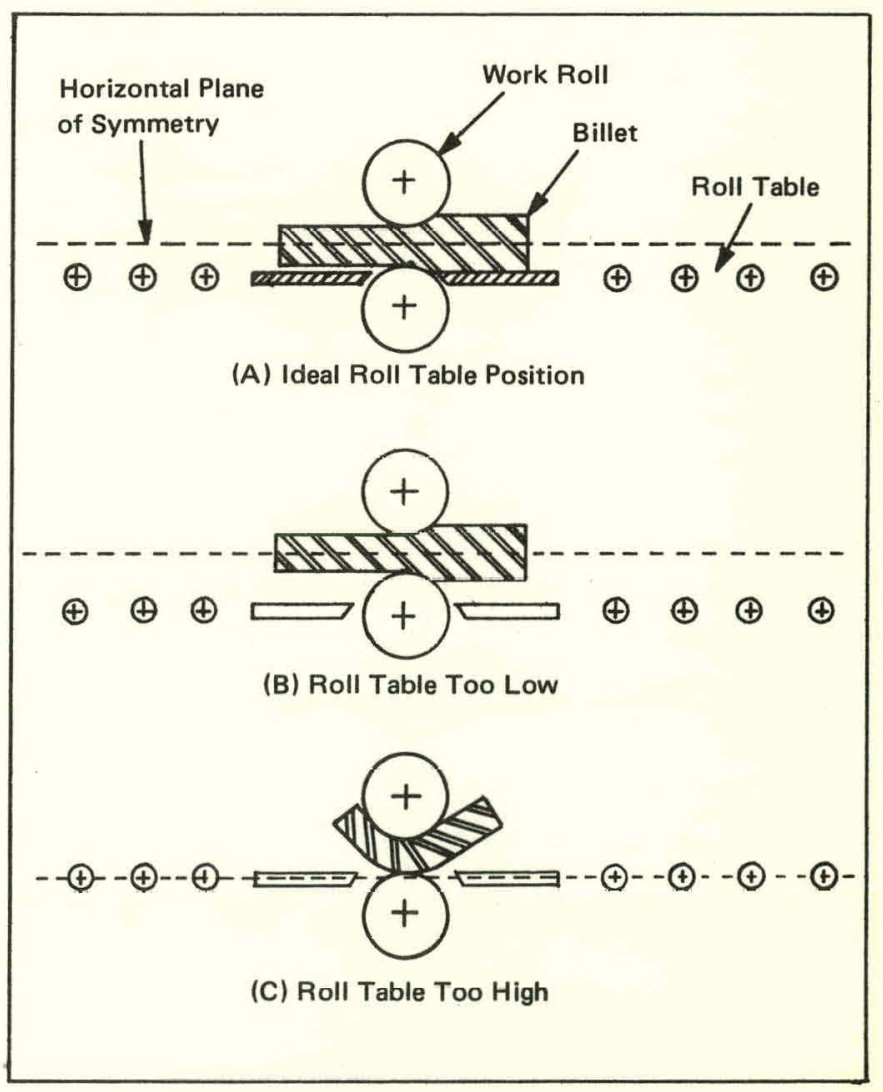


roll-table position would vary from 0.150 - to 0.020 in. below the horizontal tangent to the bottom work roll. We have found that it is better to leave the roll tables at 0.100 -in. below the tangent than to adjust them to various positions during rolling. This position is an effective compromise.

Normally we use the side guides on the mill to ensure that the billet enters the mill squarely and centered. Sometimes, especially when the billet has curled, it is necessary to "cock" the billet slightly so that a corner enters the rolls first. This can affect the vertical angle of entry. For example, the back end of the billet may be raised to make the corner enter the mill. Quite often this promotes curling again, and this is a reason why it is hard to prevent more curling once it has started.

Sometimes the billet must be flipped over so that the bottom side becomes the top side. Most often flipping is done to a billet which has curled upward. The billet then has a concave-down curvature when it enters the rolls. This helps prevent a curl in the billet as it exits the rolls. We have even tried rolling schedules wherein we flip after each pass to help maintain a uniform surface temperature. Direct contact with the cold rolls tends to chill the bottom billet surface selectively. However, we find that it is better to use a standard schedule wherein flipping is only done prior to pass 12 than to allow flipping at the discretion of the mill crew. This helps ensure a process that is constant from one day to the next. Experience has shown that it is also important to flip the billets and rotate them end-for-end after each of the last four passes. The friction factors that prevent upward curling in the first two rolling stages combine to cause downward curling of the leading edge in the final stage. Only the first few inches of the sheet curl, and the rest of the sheet is flat. The cross-section resembles a cross-section of a ski with its tip down. When the billet is flipped (putting the tip up), the flat surface rests on the roll table and the curl is concave-upward. Flipping is done immediately after rolling so that the billet can be transported down the roll tables to the furnace without rocking up and down as the result of the curled edge. Turning it end-for-end is also done at this time so that when the billet enters the work rolls for the next pass, the leading edge is flat.
Having just been reduced $20 \%$ in thickness, the beryllium is brittle on exiting from the work rolls. Flipping must be done gently. Dropping the billet from a 6-1n. height onto the roll table can crack the beryllium within. The billet must be returned to the furnace quickly so that the can does not contract and crack the brittle beryllium. Shearing of the composite must not be done until a 4-hour anneal at $1400^{\circ} \mathrm{F}$ is given to the beryllium to restore its ductility.

Before leaving the external variable category, the condition of the rolls should be discussed. We use alloy steel rolls which are case-hardened to a Shore scleroscope reading of 90 . One must be careful to have the same hardness on top and bottom work rolls or the roll flattening may vary, causing curling. We have successfully hot-rolled beryllium using a crown of 0.002 in. in our work rolls (larger diameter in the center than edges of rolls), although we presently grind our rolls flat and parallel within 0.0002 inch. We have placed dial indicators against the work rolls, both at the mill center line and near the edges, to check for eccentricity as the rolls turn. The gauges do not vary by more than 0.003 inch. During a roll pass there is some lateral motion of the top work roll. As measured by these same dial indicators, it is about 0.030 inch. Sometimes the motion is in the direction that the billet is being rolled and sometimes it is $180^{\circ}$ from that direction. No correlation of this lateral movement with our curling problems could be established.

\section{CAN VARIABLES}

Problems with curling and can rupturing may bc attributable to the can itself. Such variables as weld quality, stainless steel quality, and can thickness are discussed below.

Ultrasonic examination of the electron-beam welds has been very effective. We have rolled a few billets containing defects found ultrasonically, such as lack of penetration or lack of fusion. This was done to calibrate the inspection technique and we found that ultrasonics may be used to accurately predict weld failures in can rolling. Such defects are routinely repaired by electron beam welding the questionable area a second time. But we were 
uncertain as to whether curling might be attributable to welding problems. Therefore, a series of four billets was deliberately welded using $50 \%$ penetration instead of the normal minimum of $80 \%$. One billet was examined after the first four passes. The other three curled badly in the critical idige, one of them failing after pass 15 and one after pass 17. A macrophoto of the pass 15 failure region is shown in Figure 17. Notice that the crack is associated with the weld root. 'I'he thinning in this region indicates that it is a ductile tensile failure as noticed with the earlier pass 15 failures. We conclude that weld quality, in this case lack of full penetration, can cause what first appears to be a rolling rather than welding problem; namely, curling and subsequent can rupture.

We are concerned about the manner in which the side rail deforms during the hot-breakdown stage. Deformation clearly begins by bending as shown in Figure 18, and we prefer that the deformation is the same on both sides of a plane through the midthickness of the billet. This is because many of the late-stage can failures are associated with nonuniform side rail breakdown as shown in Figure 19. If the side rail deformation is uniform, the weld overbead on the top surface is directly above the bottom weld overbead. The overbead locations are shown in Figure 19. Instead of deforming into a cross section resembling the letter " $C$ ", the siderail has deformed into a cross section that resembles a sideways letter "J". This stretches the top cover plate more than the bottom one giving rise to the ductile, thinning type of fracture. Typically, if uniform side rail breakdown is achieved, both cover plates will measure 0.040 in. after can rolling according to the schedule in Table 3 . But if nonuniform breakdown occurs, one cover plate will be about 0.035 -in. thick and the other about 0.045 in. thick. Failures occurring in the final four passes are most often found in the thinner cover plate.

If friction conditions are correct, uniform side rail breakdown, as measured by the relative positions of the weld overbeads, is not a problem. But one way to help ensure uniform brcakdown is to use side rails which are thinner than cover plates.

With one series of eight billets, we used 0.5 -in. side rails and standard 0.600 -in. thick cover plates. One of the eight failed in the weld zone because the

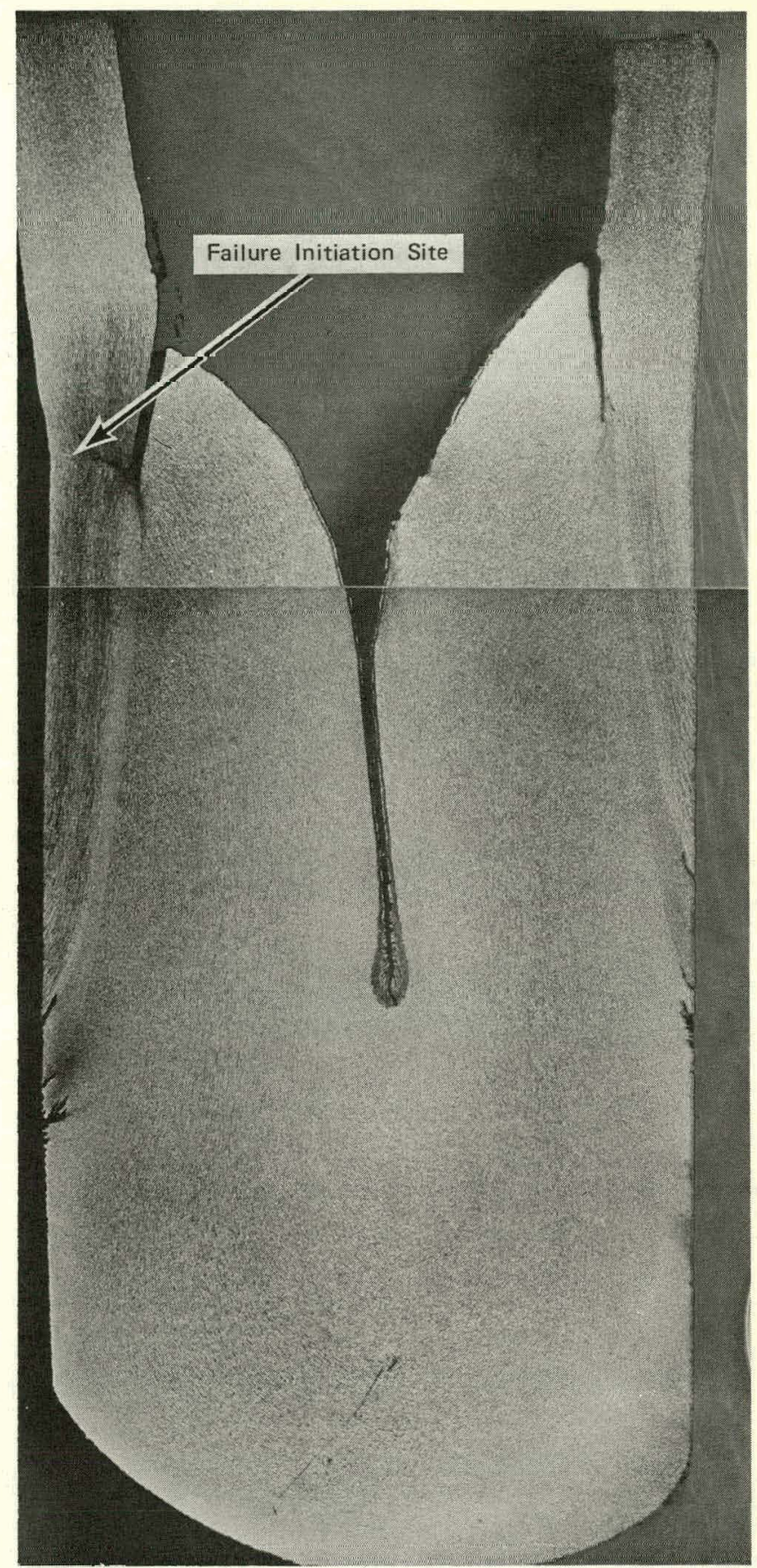

Figure 17. The 15th Pass Failure on Billet Number 3040A. (50\% weld penetration.) This failure was not typical of failures occurring on this pass because the initiation site was at the root of the weld.

electron beam missed the joint, but the other 7 rolled well. Side rail breakdown, as measured by the position of the weld overbeads on the top and bottom surfaces, was uniform. Also, curling during 


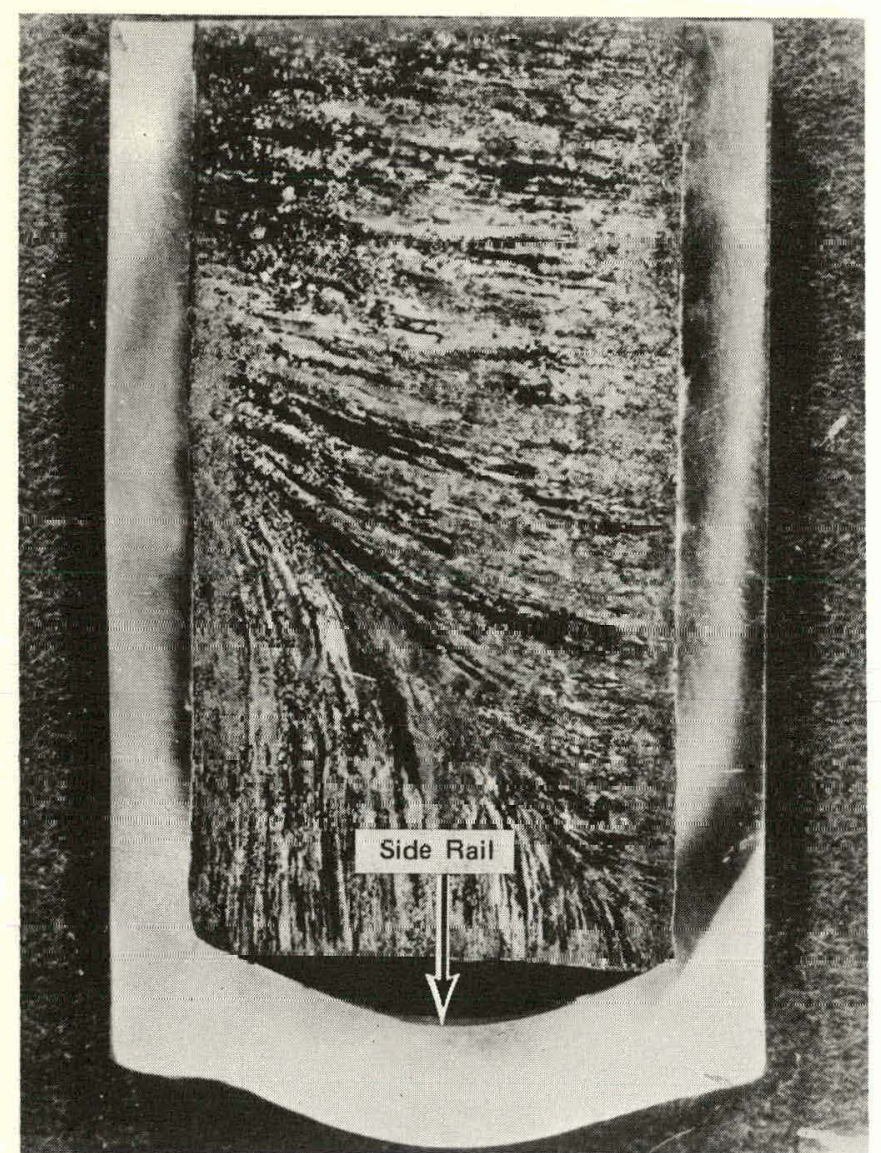

Figure 18. Macrostructure of Billet Number 3043A. After four rolling passes with $50 \%$ weld penetration. The beryllium has been etched to reveal the columnar cast structure.

rolling was nominal. These results are encouraging and we are pursuing this approach. We are also experimenting with hammer-forging to a thickness comparable to that achieved by the first four rolling passes to facilitate uniform side rail breakdown. This method also saves rolling time.

We have examined the variable of can thickness, where both the side rails and cover plates had the same thickness. Thicknesses ranging from $0.375 \mathrm{in}$. to $0.750 \mathrm{in}$. were tried. All the 0.375 -in. cans failed, half of the 0.5 -in. cans failed, but none of the 0.625 -in. or 0.750 -in. thick cans failed. We conclude that the 0.625 -in. thick cans are best.

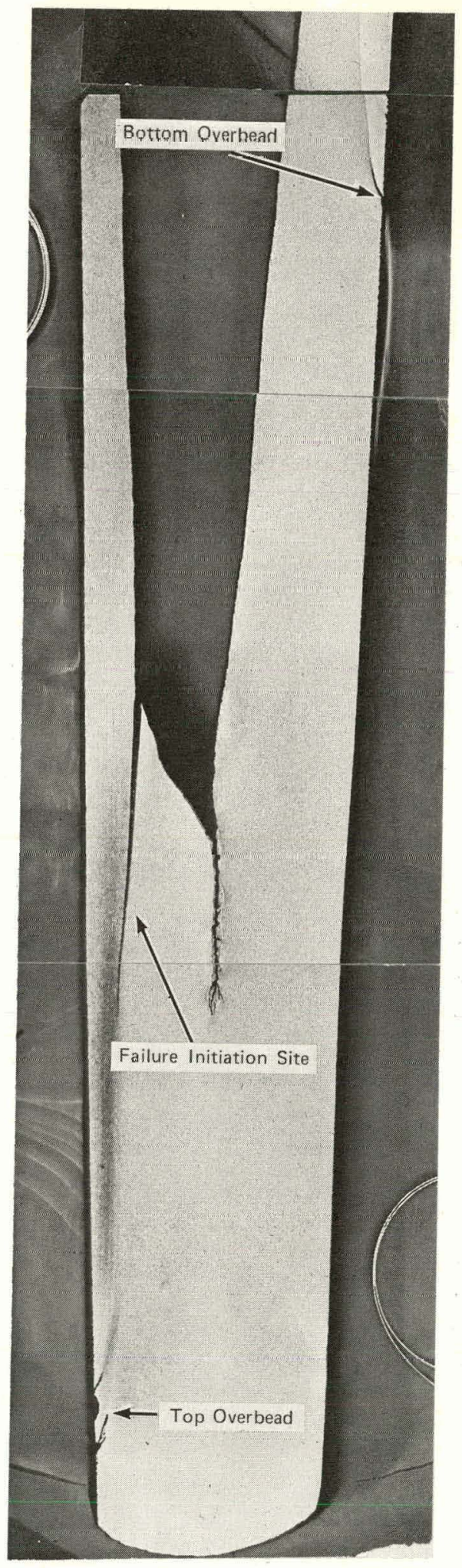

Figure 19. Failure Area of Billet Number 3044A. Note the nonuniform side rail breakdown of this billet. Failure occurred on rolling pass 17. 
We have tried once again to use mild steel cans even though they proved unacceptable in our early development work. The renewed interest stemmed from the improved cold-working characteristics of mild steel at $1400^{\circ} \mathrm{F}$, which give us more flexibility to experiment with the rolling schedule. We are still disappointed with the rough as-rolled surface, but subsequent bare rolling causes a uniform surface. The biggest problem with mild steel is a greater tendency to retain cast structure. This is due to the poor strength of mild steel in the hot-breakdown range. In this temperature range, grains of certain orientations may indent the can rather than deforming with adjacent beryllium grains.

We have examined the variable of stainless steel quality. We noticed that different heats of steel required different welding parameters, and we saw some correlation of rolling problems with different heats of steel. Extensive chemical analyses and mechanical tests have failed to reveal the reasons for these differences. We did find an apparent correlation between high silicon content in the Type-304 stainless steel and lack of full penetration in electron beam welding.

A special order of Type 304-L, low-carbon stainless steel, was obtained and used to can several billets. No significant differences, either in rolling or welding, were observed between low carbon and normal Type-304 stainless steel.

At one point we were concerned that pressure might be building up in the welded can during the solutionizing anneal. Such pressure could arise from outgassing of machining oil used when the beryllium billet was sawed. A vacuum-bake of the billets is now used to prevent this.

\section{DISCUSSION}

This report represents an attempt to organize results of numerous experiments, most of which were performed to solve immediate production problems. It is hoped that the results will be useful to others concerned with hot-rolling of dissimilar metals.

The most serious problem encountered in this work has been curling during rolling. Curling occurs at a roll diameter-to-thickness ratio of about 12 to 1 . For our rolling mill, this corresponds to a thickness of about one inch. The most significant variable controlling curling is friction between the work rolls and the rolling billet. Friction, in turn, depends most strongly on lubrication and the surface finish of the work rolls. Curling occurs toward the roll having the higher friction coefficient. Upward curling is bad because the work piece is not restrained in this direction and a tight radius of curvature may result. Downward curling is restricted by contact between the work piece and the roll table. Experience has shown that it is best to adjust the friction variable to favor a slight downward curl. This is done by lightly lubricating the top rolls while keeping the bottom rolls dry. Also, the bottom work roll is given a rougher surface finish than the top work roll. These two factors, lubrication and surface finish, cause the bottom-work roll to have a higher friction coefficient during rolling than the top work roll. Hence, slight downward curling occurs, limited by the roll table. These adjustments are the main reason why, at one time, the loss rate in can rolling was cut from $33 \%$ to less than $1 \%$.

Another critical factor in beryllium rolling is temperature control. This factor is essential for the complete conversion of the columnar and caststructure to an equiaxed and wrought structure. Results of this work show that a narrow range of temperature exists within which conversion is complete. Material rolled outside of this range usually has evidence of retained cast grains in its microstructure. Close control of the operation by the rolling crew is necessary to prevent the billets from falling out of this narrow temperature range. Faulty thermocouples, delays in getting billets back into the rolling furnace for reheats, not allowing sufficient reheat time, putting too many billets in a furnace, and using undersized furnaces may cause the range to be violated.

An important aspect of this work is the choice of canning material. Type 304 stainless steel is used principally because it has adequate high temperature strength and is suitable for electron beam welding. A disadvantage of the stainless steel is its tendency to cold work and then crack during 
the $1400^{\circ} \mathrm{F}$ grain refinement stage of rolling. Mild steel would be the most ideal alternative material for canning because of its low cost, good weldability, and absence of cold working at $1400^{\circ} \mathrm{F}$. But mild steel exhibits low strength in the hotbreakdown temperature range between $1800^{\circ} \mathrm{F}$ and $1900^{\circ} \mathrm{F}$. Beryllium grains in certain orientations resist deformation in this range and are stronger than the mild steel. Instead of deforming along with the neighboring grains, these grains indent the mild steel. Consequently, they are not reduced as much as most other grains in the hot-breakdown stage, and they do not recrystallize. These grains, when present in sheet, significantly reduce the mechanical properties of beryllium. Therefore, mild steel is not a favored canning material.

\section{REFERENCES}

1. J. L. Frankeny and D. R. Floyd, "Ingot Sheet"Beryllium Fabricaliun," USAEC RFP-910. Rucky Flals Dip̣isịun, Dow Chemical U.S.A., February 9, 1968.

2. F. J. Fraikor, V. K. Grotzky, A. W. Brewer, and H. E. Reed, "Precipitation Characteristics of Rocky Flats Beryllium Ingot Sheet," USAEC RFP-1041. Rocky Flats Division, Dow Chemical U.S.A., March 12, 1968.

3. D. R. Floyd, "The Effect of Hydrostatic Processing on the Malleability of Brittle Materials," USAEC RFP-1383, Rocky Flats Division, Dow Chemical U.S.A., May 12, 1970.

4. C. R. Heiple, "Factors Affecting Curling in Rolled Sheet," Transactions ASME, Journal of Engineering Materials and Technology, Vol 95, Series H, No. 2, April 1973, p 103. 